\title{
Estudo da resposta imune humoral em mulheres com neoplasia ovariana.
}

Dissertação apresentada ao Curso de PósGraduação em Ginecologia, Obstetrícia e Mastologia - área de concentração Tocoginecologia, da Faculdade de Medicina de Botucatu da Universidade Estadual Paulista, para obtenção do Título de Mestre em Ginecologia

Orientador: Professor Dr. Agnaldo Lopes da Silva Filho

Co-orientadora: Dra. Andréa Teixeira de Carvalho

\section{Botucatu / São Paulo}

2010 
FICHA CATALOGRÁFICA ELABORADA PELA SEÇÃO TÉCNICA DE AQUISIÇÃO E TRATAMENTO DA INFORMAÇÃO

DIVISÃO TÉCNICA DE BIBLIOTECA E DOCUMENTAÇÃO - CAMPUS DE BOTUCATU - UNESP BIBLIOTECÁRIA RESPONSÁVEL: Selma Maria de Jesus

Freitas, Gustavo Ferreira de.

Estudo da resposta imune humoral em mulheres com neoplasia ovariana /

Gustavo Ferreira de Freitas. - Botucatu, 2010.

Dissertação (mestrado) - Faculdade de Medicina de Botucatu, Universida-de Estadual Paulista, 2010

Orientador: Agnaldo Lopes da Silva Filho

Co-orientador: Andréa Teixeira de Carvalho

Assunto CAPES: 40101150
1. Ginecologia
2. Ovários - Doenças
3. Resposta imune humoral

Palavras-chave: Câncer epitelial de ovário; Citometria de fluxo; Imunofenotipagem; Resposta imune adaptativa 


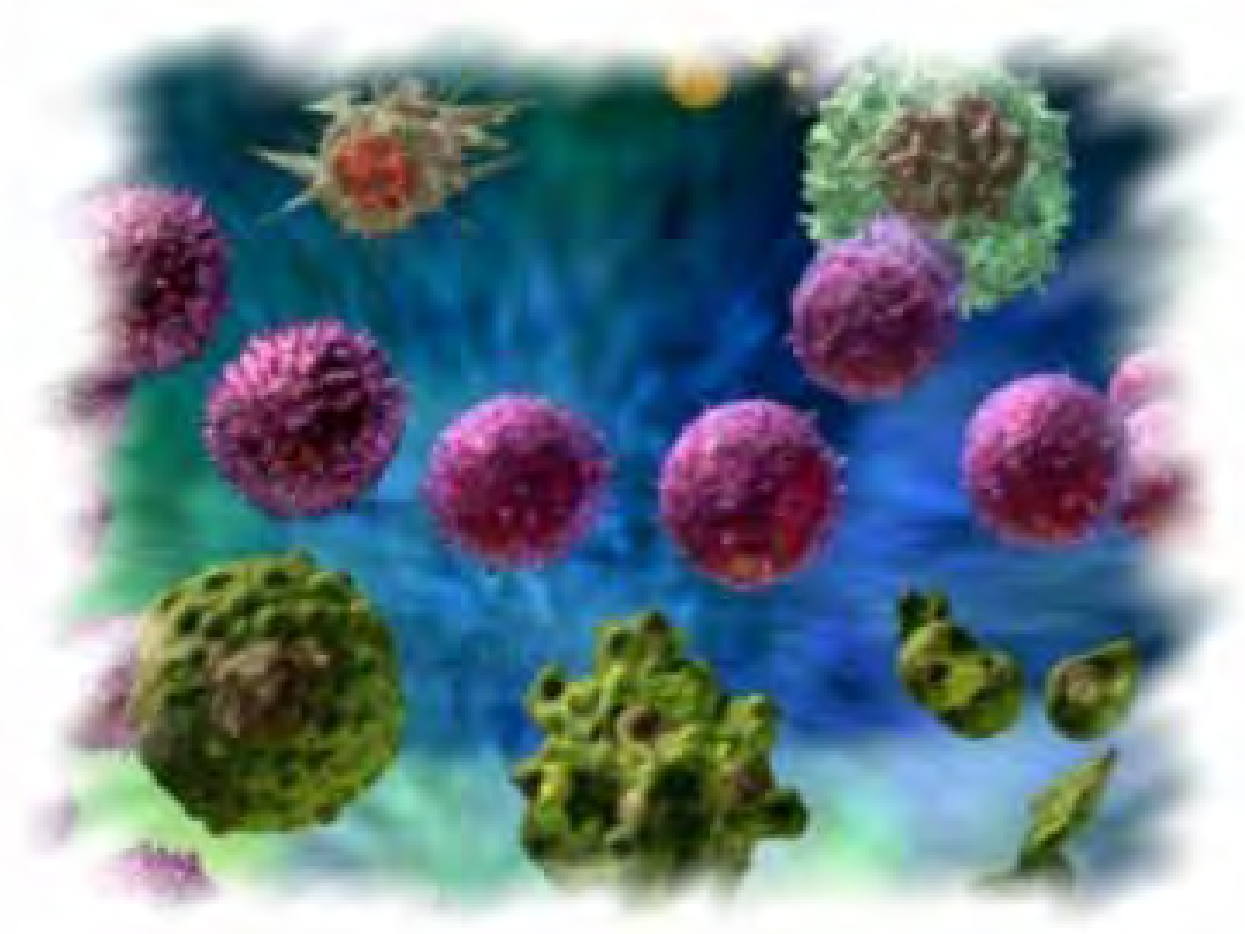

Dedicatária 


\title{
Dedico esta tese...
}

\author{
as mens pais, Luize Vera. \\ Muita abrigada pela apaia e dedicaçãa.
}




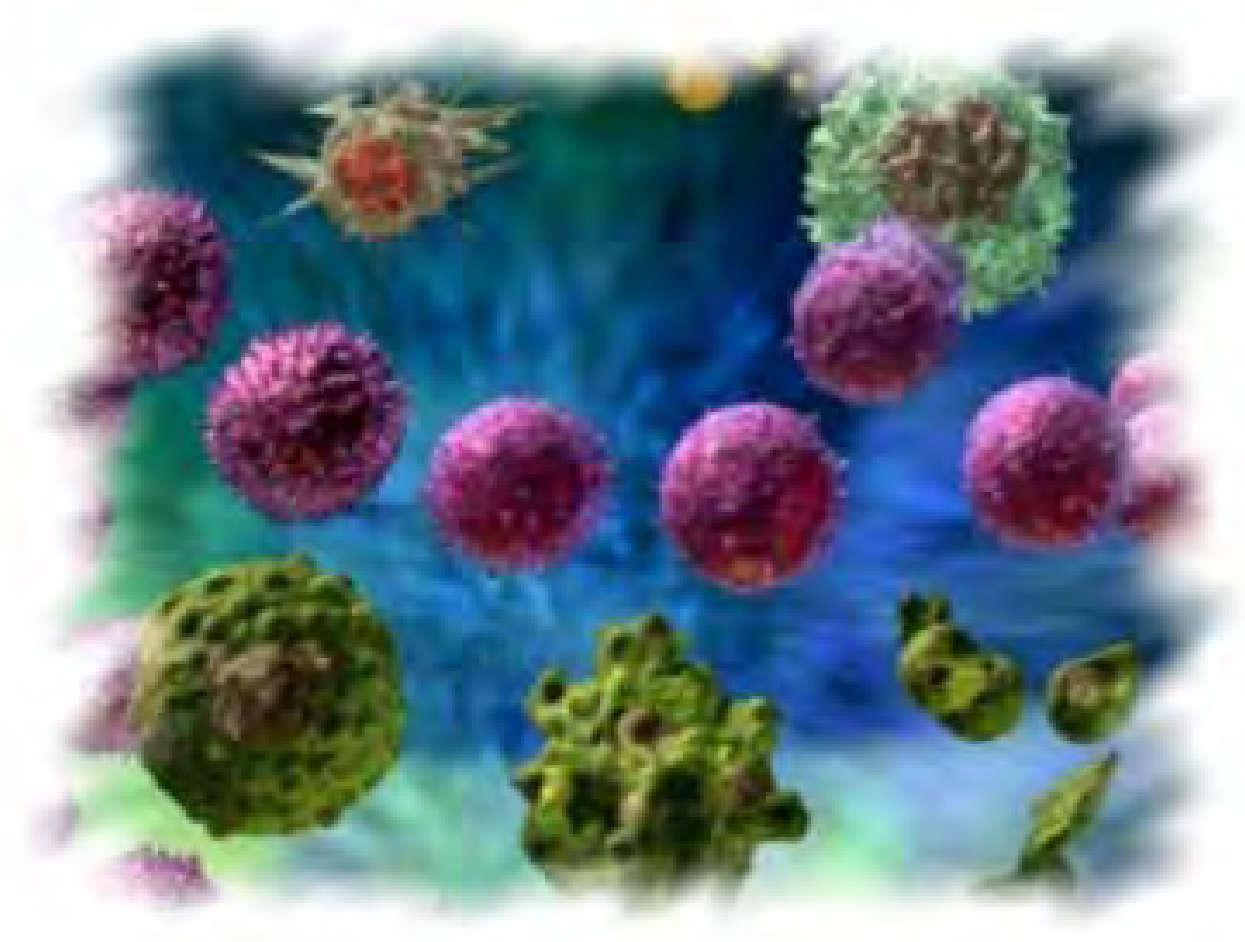

Agradecimentas 
Aa Dr Agnalda Lapes da Silva Filha pela apartunidade de trabalhar salv a sua arientaçãa na realizaçãa dessa dissertaçãa. Pela privilégia de pader campartilhar sua sabedaria.

A Dra Andréa Teixeira de Carvalha, pelas ensinamentas em imunalagia e citametria, pela dispanililidade em arientar e acima de tuda pela exempla de pesquisadora. 
Aa Dr. Clinda que abrim as partas da sew labaratária para realizaçãa deste trabalha.

A Dra Telma e tada sua equipe da Maspital Mária Penna, pela auxilia na triagem das pacientes e da caleta da material bialágica.

Aa Dr. Agnalda e tada sua equipe da Maspital das Clinicas da UFM C. pela auxilia na triagem das pacientes e da caleta da material bialágica.

As pacientes cuja participaçãa fai imprescindivel para a realizaçãa deste trabalha.

Aa Praf. Nery Cunha Vital, pela amizade e incentiva canstante da lusca pela canhecimenta.

Aas amigas da Labaratária de Biamarcadares de Diagnástica e Manitaraçãa e da Labaratária de Imunalagia Celular e Malecular pela rica canuivência.

Márcia, Denise, Matheus, Melena, Raberta Dias abrigada pela ajuda, incentiva e grata canuivência.

Tiza e Fabiana pela apaia técnica de qualidade.

A Raberta Felix e Maisa, par sempre estarem dispanúcis e auxilia cam a parte luracrática.

Aas amigas, em especial à Sálua, companheira de mestrada.

Aas calabaradares da Setar de Pás-Cyraduaçãa da Faculdade de Medicina de Batucatu da UNESP, Regina, Nathanael, Tanete e Ana Clándia, pela dispanibilidade e preciasa ajuda.

Aas prafessares da Pás-graduaçãa da Departamenta de Cinecalagia e Clstetrícia da Pósgraduaçãa da Faculdade de Medicina de Batucatu da UVESP pelas ensinamentas. Em especial aa Prafessar Paula Traiman, pela canstante incentiva e apaia durante esta trajetária.

A Elisa par sempre estar aa mew lada. Esta canquista é nassa.

Aa mew irmãa Bruna, pela amizade.

Em especial aas meus pais, par dedicarem sua vida à minha farmaçãa intelectual e maral. 
Finalmente, à minha família e amigas, par estarem presentes em tadas as mamentas, sempre tarcenda pela men sucessa. 


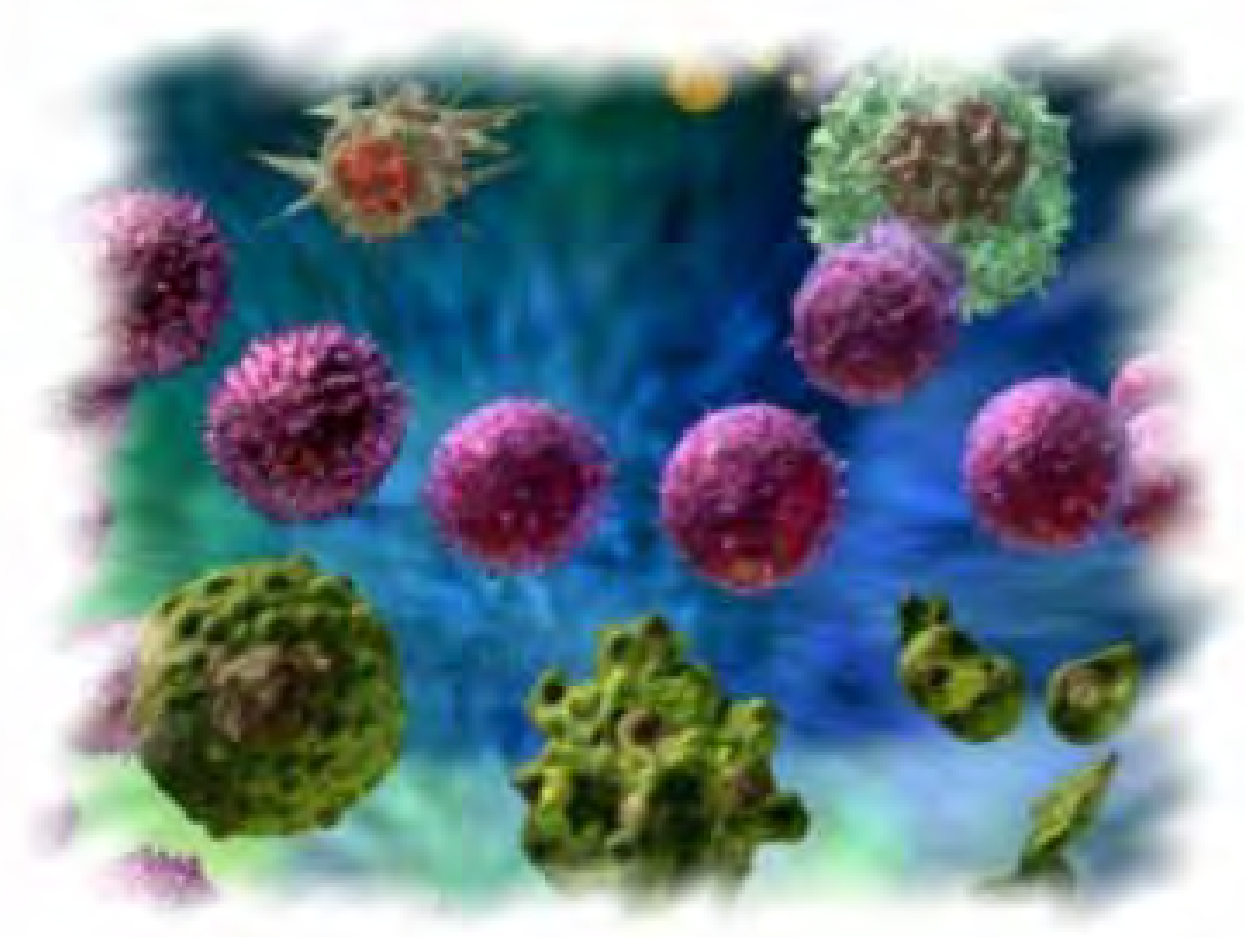

Epigrafe 
"Se vacê encantrar um caminha sem alestáculas, ele pravavelmente nãa leva a lugar nenhum"

Frank Clark 


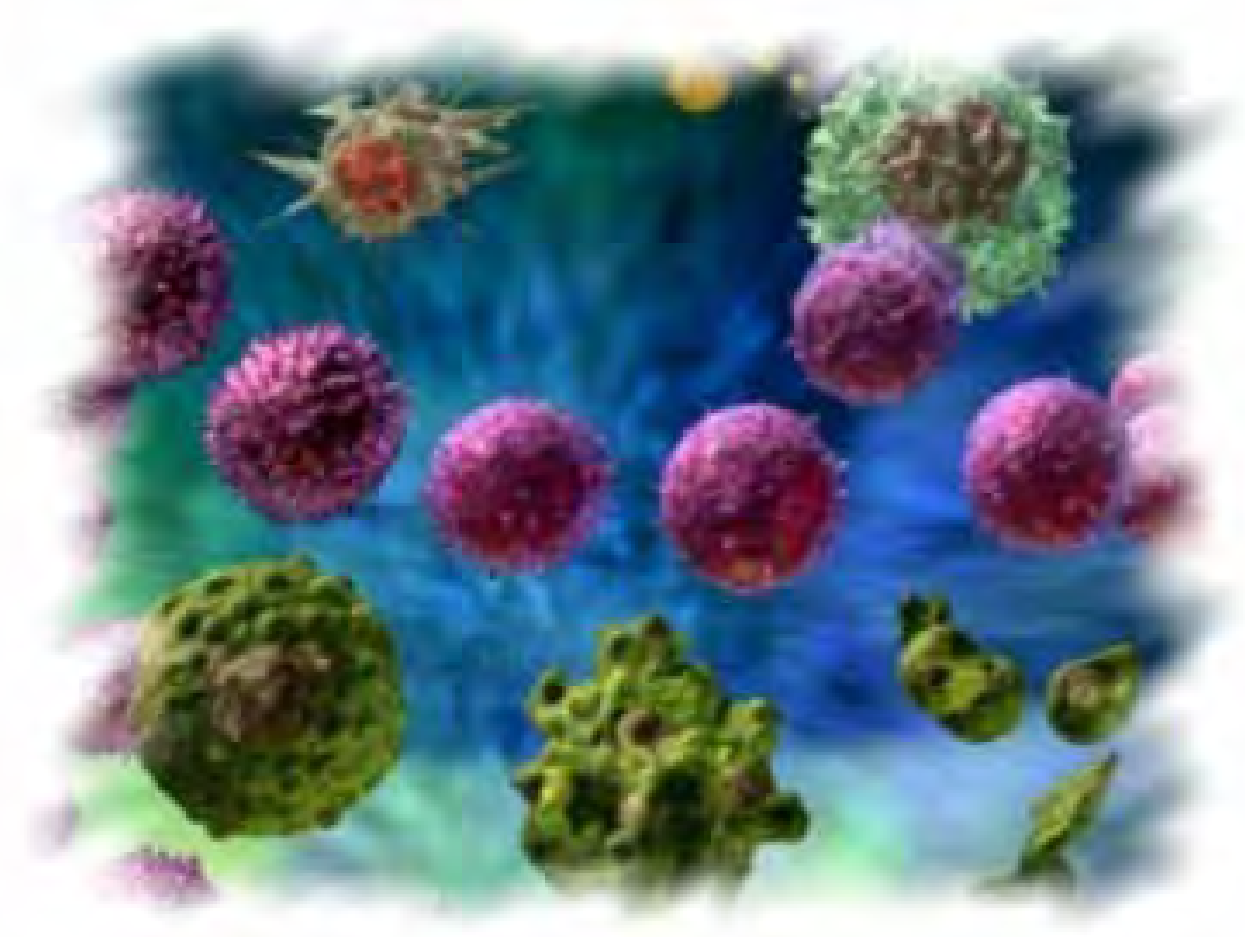

Óndice 


\section{Siglas}

\section{Resumo}

1. Introdução.

1.1. Câncer epitelial do ovário ......................................................... 20

1.2. Resposta imune ................................................................... 20

1.3. Sistema imune e câncer ................................................... 23

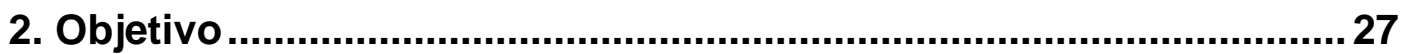

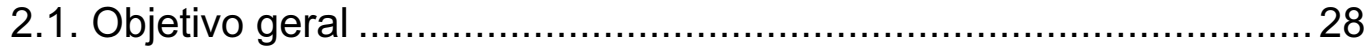

2.2. Objetivos específicos........................................................... 28

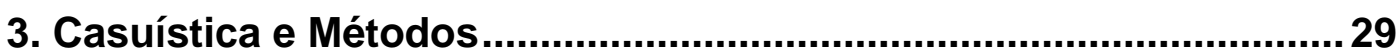

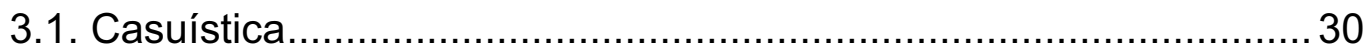

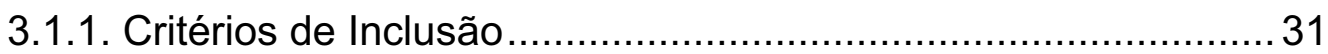

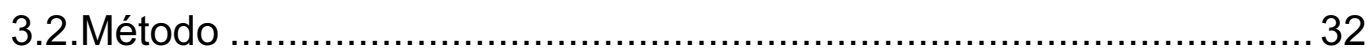

3.2.1. Análise por Citometria de Fluxo - Protocolo de imunofenotipagem celular ............................................................ 32

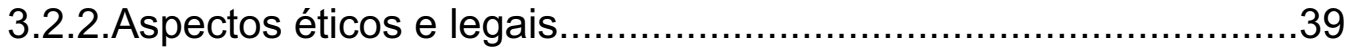

3.2.3 Análise Estatística.............................................................39

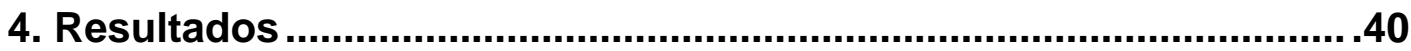

4.1. Características gerais da amostra ....................................... 41

4.2. Análise ex vivo da porcentagem de linfócitos $T$ (CD4+ e CD8+), linfócitos $T$ auxiliares (CD4+) e linfócitos T citotóxicos (CD8+) do sangue periférico de mulheres do grupo controle, neoplasia benigna e maligna.

4.3 Análise ex vivo da porcentagem de linfócitos B (CD19+) do sangue periférico de mulheres do grupo controle, neoplasia benigna e maligna ................................................................................... 44

4.4 Análise ex vivo da porcentagem de moléculas de ativação celular por linfócitos T CD4+ e T CD8+ do sangue periférico de mulheres do grupo controle, neoplasia benigna e maligna.

4.5 Análise ex vivo da porcentagem de moléculas de adesão celular por linfócitos T CD4+ e T CD8+ do sangue periférico de mulheres do grupo controle, neoplasia benigna e maligna.

4.6 Análise ex vivo da porcentagem de linfócitos T $\mathrm{CD}^{+} \mathrm{CD} 25^{+} \mathrm{e}$ linfócitos $\mathrm{T} C D 4^{+} \mathrm{CD} 25^{+\mathrm{HIGH}}$ do sangue periférico de mulheres do grupo controle, neoplasia benigna e maligna..............................48

4.7 Análise ex vivo da porcentagem de receptores de quimiocinas em linfócitos TCD4+ e TCD8+ do sangue do sangue periférico de mulheres do grupo controle, neoplasia benigna e maligna............49

4.8 Análise ex vivo da porcentagem de linfócitos $\mathrm{B}$ ativado (CD19+CD69+), linfócitos B1 (CD19+CD5+) e linfócitos B2 $(C D 19+C D 23+)$ do sangue periférico de mulheres do grupo controle, neoplasia benigna e maligna.. 


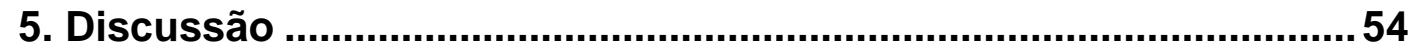

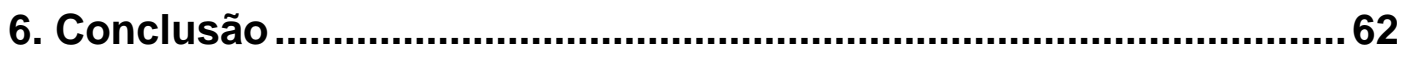

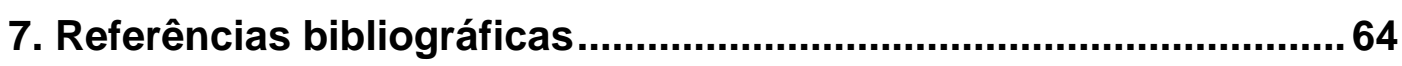

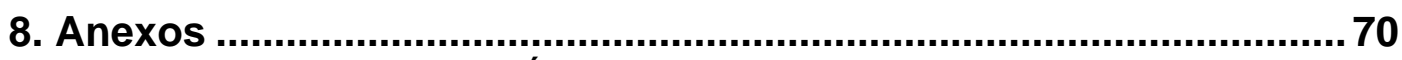

I. Parecer do Comitê de Ética em Pesquisa (CEP) ..............................71

II. Consentimento livre e esclarecido............................................... 72

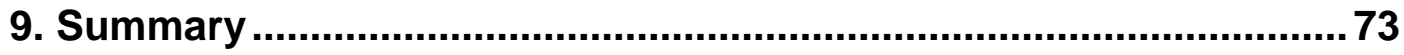




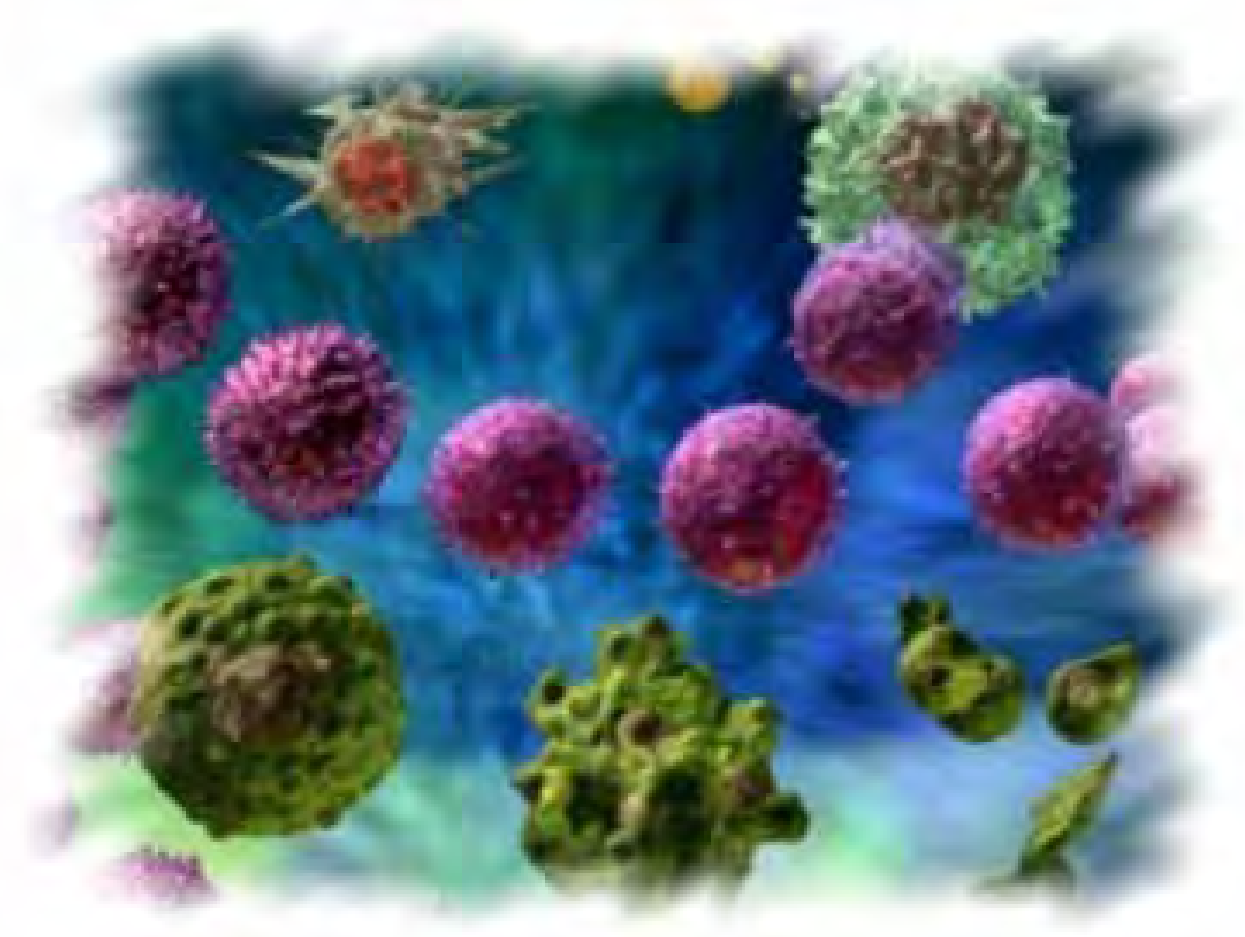

Siglas 


\begin{tabular}{|c|c|}
\hline Abs & Anticorpos \\
\hline ADCC & citotoxicidade celular dependente de anticorpo \\
\hline CEO & Câncer Epitelial de Ovário \\
\hline CEP & Comitê de Ética em Pesquisa \\
\hline CMF & Citometria de Fluxo \\
\hline CYCHR & Cyhrome \\
\hline $\mathrm{DC}$ & Células dendríticas \\
\hline EDTA-K3 & ácido etileno-diamino tetracético \\
\hline FACS & Fluorescence-Activated Cell Sorting \\
\hline FIGO & Federação Internacional de Ginecologia e Obstetrícia \\
\hline FITC & Isoticianato de fluoresceína \\
\hline FSC & Forward Scatter \\
\hline $\mathrm{mm}$ & milímetro \\
\hline NK & natural killer \\
\hline $\mathrm{nm}$ & nanometro \\
\hline PBMC & células mononucleares de sangue periférico \\
\hline PE & Ficoeritrina \\
\hline PerCP & Peridin Chlorophyll Protein \\
\hline SSC & Side Scatter \\
\hline TAA & antígenos associados ao tumor \\
\hline $\mathrm{TC}$ & Tricolor \\
\hline$\mu \mathrm{L}$ & Micro litro \\
\hline $\mathrm{MHC}$ & molécula do complexo maior de histocompatibilidade \\
\hline
\end{tabular}




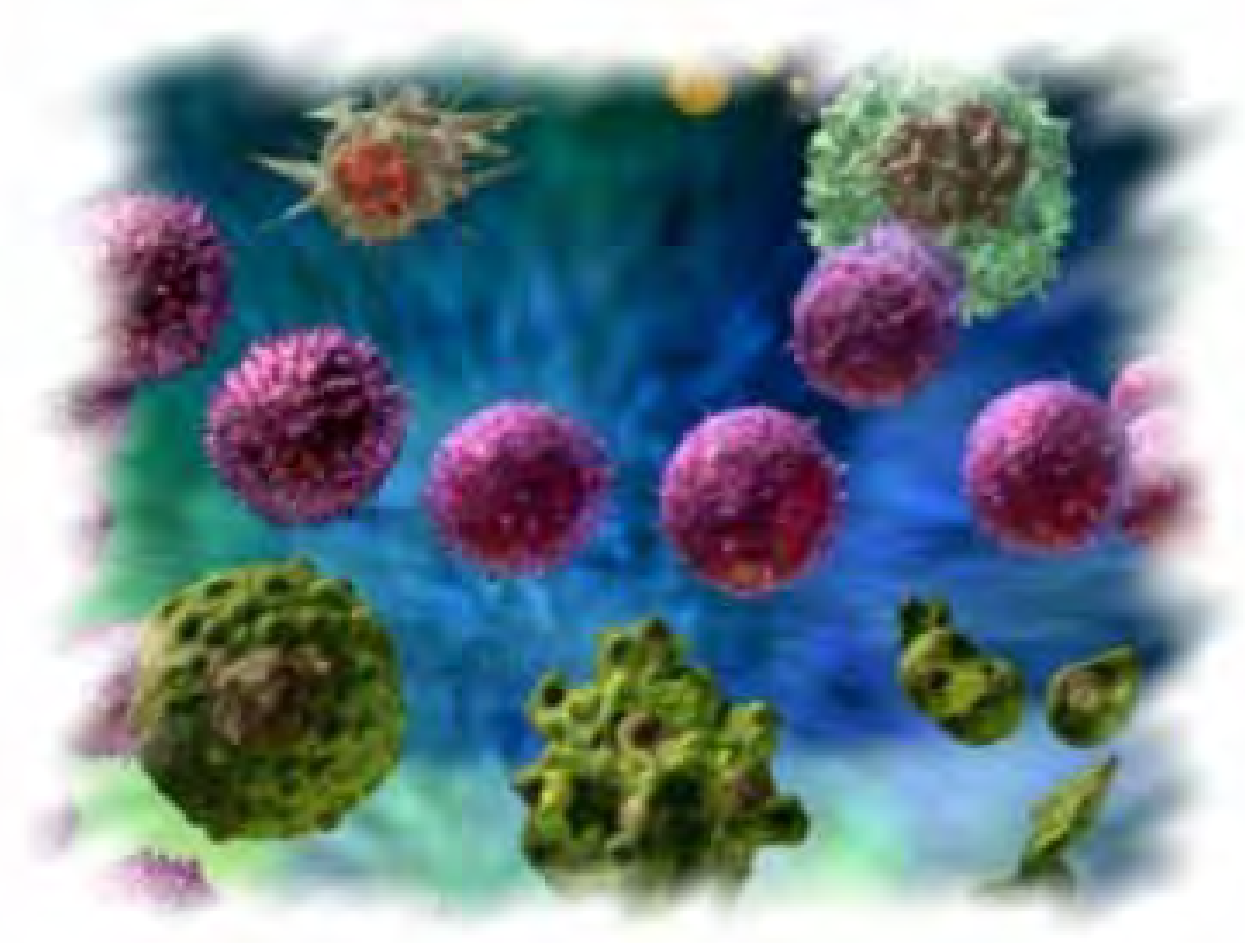

Resuma 
Introdução: O câncer epitelial do ovário representa um desafio à Oncologia Ginecológica devido ao seu caráter insidioso e alta letalidade. Evidências apontam para o conceito de que o sistema imunológico interage com o tumor em desenvolvimento e pode ser responsável pelo controle do crescimento e regressão tumoral. A resposta imune adaptativa no ambiente tumoral, inclui a imunidade humoral composta de anticorpos produzidos pelas células $\mathrm{B}$ e da imunidade celular composta de células T CD4+ e células T CD8+. Este estudo visa avaliar a resposta imune adaptativa sérica em mulheres com neoplasia ovariana.

Métodos: Foram analisadas amostras de sangue periférico obtidas de mulheres hígidas ( $n=10$ - grupo controle), com tumor benigno de ovário $(n=9)$ e com câncer de ovário ( $n=17)$. As amostras foram avaliadas pela técnica de citometria de fluxo, onde utilizou-se 5 parâmetros: tamanho celular , complexidade interna e três fluorescências: FITC, PE e TC. O painel de anticorpos monoclonais incluiu os marcadores: CD4, CD8, HLA-DR, CD54, CD62L, CD18, CCR2, CXCR4, CCR5, CCR3, CXCR3, CD25, CD5, CD69, CD19, CD23, e controle isotípico. As diferenças entre os grupos foram avaliadas pelo teste de Mann-Whitney ou Kruskal-Walis conforme indicados. As diferenças com valor de $p<0,05$ foram consideradas significativas.

Resultados: Houve uma diminuição estatisticamente significativa $(p<0,05)$ da porcentagem de células $\mathrm{T}$ do grupo de mulheres com câncer de ovário quando comparado ao grupo controle. A análise dos resultados mostrou que o percentual de linfócitos T CD4+ apresentou diferenças significativas entre os grupos $(p=0,0399)$. Entretanto a população de linfócitos T CD8+ não apresentou diferenças significativas $(p=0,2939)$. A análise de percentual de linfócitos $B(C D 19+)$ identificou diferença significativa na comparação entre os três grupos avaliados $(p=0,0463)$. Foi observado uma diminuição do percentual de células $B$ dos grupos de mulheres com tumor benigno e câncer de ovário em relação ao grupo controle. Dentre as moléculas de adesão celular avaliadas (CD54, CD62L, CD18) verificou-se diminuição significativa $(p<0,05)$ do número de linfócitos TCD4+ CD62L+ no grupo de mulheres com câncer de ovário quando comparado com o grupo de mulheres com tumor benigno. No grupo de mulheres com câncer de ovário foi observada diminuição significativa $(p<0,05)$ do número de linfócitos TCD8+ CD62L+ quando comparado ao grupo controle. Foi possível observar diferença estatisticamente significativa entre os grupos CD8+CCR2+ $(p=0,0294), C D 8+C C R 5+(p=0,0216)$ e CD4+CCR3+ $(p=0,0233)$. 
Conclusão: É possível observar a participação de leucócitos circulantes no sangue periférico em pacientes com neoplasia ovariana, mostrando que os eventos fenotípicos caracterizam a presença de manifestação sistêmica.

Palavras-chave: Câncer epitelial de ovário, resposta imune adaptativa, imunofenotipagem, citometria de fluxo. 


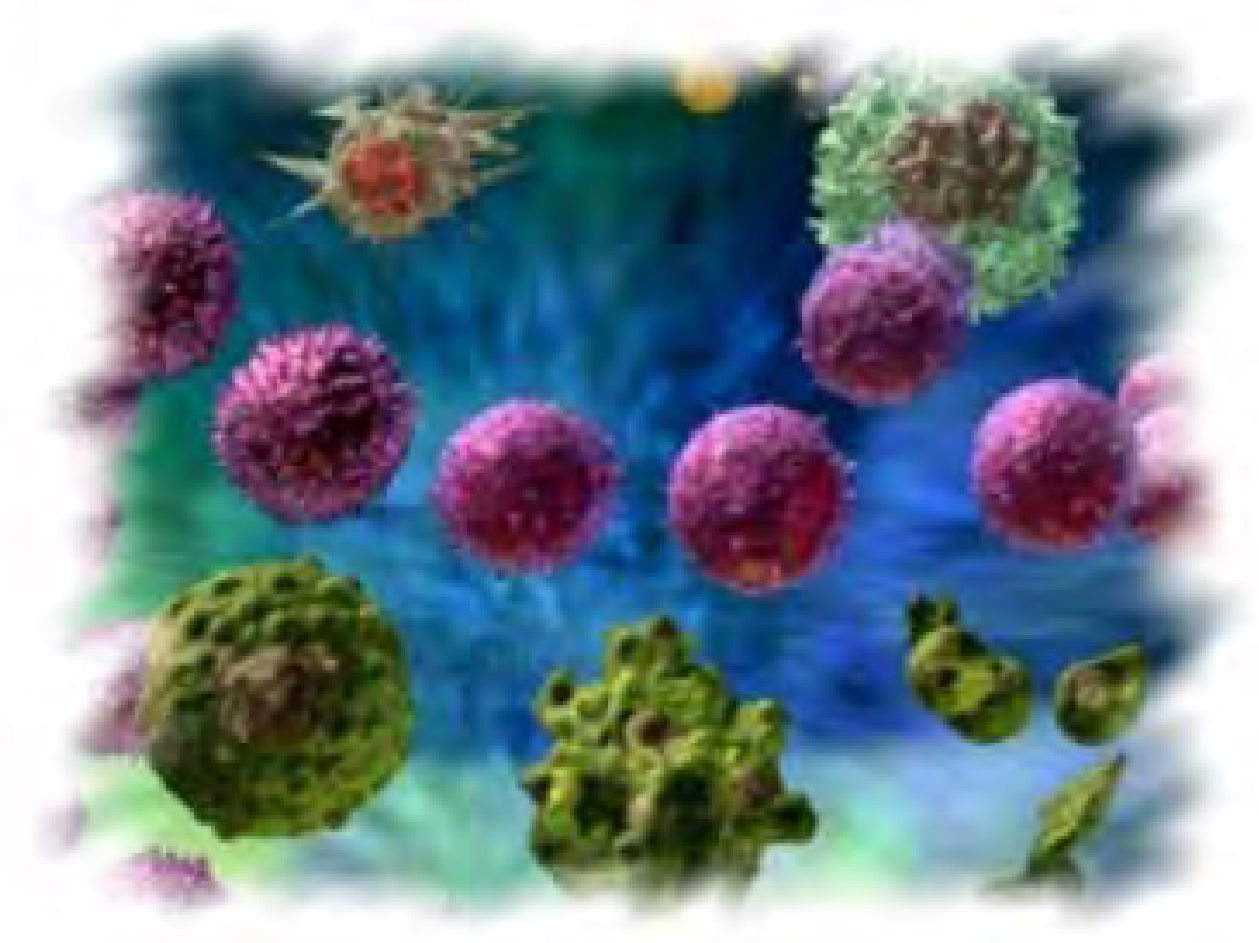

1. Intraduçãa 


\subsection{Câncer epitelial do ovário}

O câncer epitelial do ovário (CEO) representa um desafio à Oncologia Ginecológica devido ao seu caráter insidioso e alta letalidade [1]. É a primeira causa de morte entre os tumores ginecológicos nos Estados Unidos e a quarta maior causa de morte entre as mulheres [2]. Para o ano de 2009, a sociedade Americana do Câncer estimou 21.550 novos casos e 14.600 mortes [3]. .A sintomatologia inespecífica e a falta de métodos propedêuticos de rastreamento dificultam o diagnóstico precoce dessa neoplasia $[4,5]$. Aproximadamente $2 / 3$ dos casos são diagnosticados nos estádios III e IV, com uma sobrevida em cinco anos variando de 10 a $20 \%$ [6].

Embora o CEO possa ocorrer em qualquer idade, é mais comum em mulheres com mais de 50 anos. O tratamento convencional inclui citorredução cirúrgica seguida de quimioterapia, quando indicada [7]. Apesar dos avanços no tratamento a mortalidade por CEO não se modificou nas ultimas duas décadas [8]

\subsection{Resposta imune}

A resposta imune pode ser dividida em inata ou adaptativa. A imunidade inata está associada às fases iniciais da resposta imune, atua contra o agente agressor de maneira inespecífica e não aumenta com a repetida exposição à esse agente [9]. A imunidade adaptativa acentua mecanismos efetores similares àqueles da resposta inata, direcionando-os com maior precisão. A resposta adaptativa pode ser determinada pela ativação de macrófagos ou pela 
produção de anticorpos [10]. A definição de qual será a via dominante está associada à diferenciação das células CD4 virgens em células $T_{H} 1$ ou $T_{H} 2$ no tecido linfóide. As células $T_{H} 1$ estão associadas à ativação de macrófagos e as células $\mathrm{T}_{\mathrm{H}} 2$ a produção de anticorpos [11]. Os mecanismos que controlam esta diferenciação ainda não estão bem definidos. Sabe-se que as citocinas e quimiocinas presentes nos tecidos no início da fase de diferenciação tem grande influência nesse processo [12].

Macrófagos e linfócitos ativados atuam de forma interativa na liberação de citocinas que amplificam a resposta imune [13].

Os linfócitos B-1 distinguem-se dos linfócitos B pela proteína de superfície celular CD5, e apresenta propriedades inteiramente diferentes daquelas observadas nas células B convencionais que medeiam a imunidade humoral adaptativa. As células B-1 são, em muitos aspectos, análogas às células $T$ epiteliais $\gamma: \delta$. Elas originam-se precocemente na ontogenia, utilizando um conjunto distinto e limitado de rearranjos de genes para produzir seus receptores. Células B-1 são linfócitos presentes nas cavidades peritoneal e pleural, que produzem anticorpos principalmente contra antígenos polissacarídicos. Podem induzir à produção de anticorpos de classe IgM sem a necessidade de células $T$ auxiliares. A falta de uma interação antígeno específica com as células $\mathrm{T}$ auxiliares pode explicar porque a memória imunológica não se desenvolve como resultado da resposta de células B-1. Repetidas exposições ao mesmo antígeno induzem respostas semelhantes ou diminuídas a cada exposição ao mesmo estímulo [14-16] 
As células $\mathrm{T}$ dividem-se em duas classes principais com funções efetoras distintas. Essas duas classes são diferenciadas pela expressão de proteínas de superfície celular, CD4 e CD8. Esses tipos de células T diferem-se na classe de molécula do complexo maior de histocompatibilidade (MHC) que eles reconhecem. Existem duas classes de molécula MHC, o MHC de classe I e o MHC de classe II, que apresentam estrutura e padrão de expressão diferente nos tecidos do organismo. A proteína de superfície celular CD4 liga-se à molécula de classe II, e CD8, à molécula de classe I. Durante o reconhecimento do antígeno, as moléculas CD4 e CD8 associam-se com o receptor de célula $\mathrm{T}$ e ligam-se a sítios invariáveis na porção do $\mathrm{MHC}$ do complexo MHC:peptídeo. Essa ligação é necessária para que a célula T realize uma resposta eficaz [17-20].

A principal função das células T CD4 é ativar outras células do sistema imune. As moléculas MHC de classe II são encontradas nos linfócitos B, nas células dendríticas e nos macrófagos. Quando as células T CD4 reconhecem peptídeos ligados a moléculas $\mathrm{MHC}$ de classe II nas células $\mathrm{B}$, ocorre $\mathrm{O}$ estímulo para a produção de anticorpos. Da mesma maneira, as células T CD4, reconhecendo peptídeos ligados às moléculas $\mathrm{MHC}$ de classe II nos macrófagos, ativam essas células para destruição do agente agressor [21].

As células T CD4 ativam células que estão envolvidas em duas categorias funcionais: as células Th1, que ativam macrófagos, e as células Th2 ou células T auxiliares, que ativam a produção de anticorpos pelas células B [22-24]. 


\subsection{Sistema imune e câncer}

Evidências apontam para o conceito de que o sistema imunológico interage com o tumor em desenvolvimento e, em alguns casos, pode ser responsável pelo controle do crescimento e regressão tumoral. A resposta imune ao câncer pode ser dividida em inata e adaptativa. Os elementos celulares da imunidade inata incluem os granulócitos, macrófagos, mastócitos, células dendríticas (DC) e natural killer (NK). A resposta inata serve como uma linha de primeira defesa contra o câncer. Em contraste, a imunidade adaptativa, que inclui a imunidade humoral composto de anticorpos produzidos pelas células B e da imunidade celular composta de células T CD4+ e células T CD8+, evolui ao longo de vários dias, refletindo a necessidade da ativação e expansão dos linfócitos que podem especificamente reconhecer antígenos associados ao tumor [25, 26].

A presença de anticorpos (Abs) para antígenos associados ao tumor (TAA), bem como células efetoras inespecíficas e específicas presentes na circulação periférica e no sítio tumoral de pacientes com câncer, tem sido freqüentemente relatadas. Essas células e os Abs são capazes de mediar a rejeição do tumor nesses pacientes. Estudos in vitro, demonstraram que células efetoras isoladas, incluindo as células T, natural killer (NK) ou macrófagos, mostraramse capazes de mediar a morte de alvos tumorais em ensaios através de mecanismos como a lise osmótica (citotoxicidade) ou apoptose e/ou 
citotoxicidade celular dependente de anticorpo (ADCC). In vivo, entretanto, os tumores parecem ter evoluído vários meios de evadir à essas células imunes. Os tumores podem escapar do sistema imune, através de uma variedade de mecanismos, e a capacidade de interferir com o número de células imunes antitumorais e/ou para subverter sua função é considerada uma das principais razões subjacentes ao fracasso do hospedeiro para controlar a progressão do tumor [27].

A interação das células tumorais com o sistema imune desempenha papel decisivo no processo da carcinogênese [25]. Estudos demonstram que infiltrados intratumorais de linfócitos, especialmente aqueles com células T CD8+, estão associados com a redução de recorrência da doença e sobrevida prolongada em diversos tipos de câncer [28-30].

A resposta adaptativa antitumoral é iniciada pelas DC, que capturam células tumorais, e processam o antígeno para o $\mathrm{MHC}$ de classe I e II As células DC migram para os gânglios linfáticos, e estimulam células $T$ e $B$ específicas para o antígeno. No microambiente tumoral, as DC podem ser ativadas por sinalização produzida por células tumorais necróticas. Ocorre processo de maturação que inclui a expressão de múltiplas moléculas de co-estimulação e citocinas, resultando na resposta mediada pelas células T [31]. Alternativamente, a produção de citocinas imunossupressoras, como TGF- $\beta$, IL-10 e VEGF, no microambiente 
tumoral, pode inibir a função dessas DC, inibindo a resposta efetora de células T e aumentando a função das células T reguladoras [32].

A resposta adaptativa às células tumorais depende da apresentação de epítopos de antígenos no sítio de ligação de moléculas do MHC classe I. O principal mecanismo de morte das células tumorais por vias específicas depende da ação de células T CD8+ que reconhecem antígenos apresentados no contexto do MHC classe I. Assim, mecanismos potenciais de evasão imune envolvem a queda da expressão dos genes do MHC classe I ou de qualquer componente envolvido nas etapas de processamento de antígenos e transporte de epítopos imunogênicos para a membrana plasmática [33].

As células NK reconhecem as células alteradas quando os linfócitos T CD8+ estão disfuncionais, ou seja, a existência das células NK não permite que a queda da expressão de MHC classe I possa ser usada como mecanismo de escape de células tumorais [34].

A imunovigilância é a capacidade do sistema imune de reconhecer um antígeno tumoral ou uma modificação no tecido envolvido e agir contra essas células Este mecanismo depende da interação dos sistemas imune inato e adaptativo. Independente do mecanismo de reconhecimento, as vias efetoras são mediadas pelo IFN-ү. Células dendríticas apresentadoras de antígenos estimulam a proliferação de células T CD4+ e CD8+ tumor-específicas. Desse modo, as células da imunidade adaptativa são atraídas para o local da neoplasia onde reconhecem e destroem as células tumorais que expressam os antígenos específicos [35]. 
Células tumorais mutadas podem tornar-se resistentes ao sistema imune [35, 36].Outra forma de escape à imunovigilância tumoral é através da liberação de citocinas inibitórias - TGF- $\beta$ ou IL-10 - ou através de modificações estruturais (perda de antígenos, perda de componentes MHC ou insensibilidade ao IFN-Y). [35].

Apesar das evidências de escape tumoral à imunovigilância, a real função do sistema imune no controle do desenvolvimento e progressão tumoral ainda constitui um grande desafio na prática clínica . 


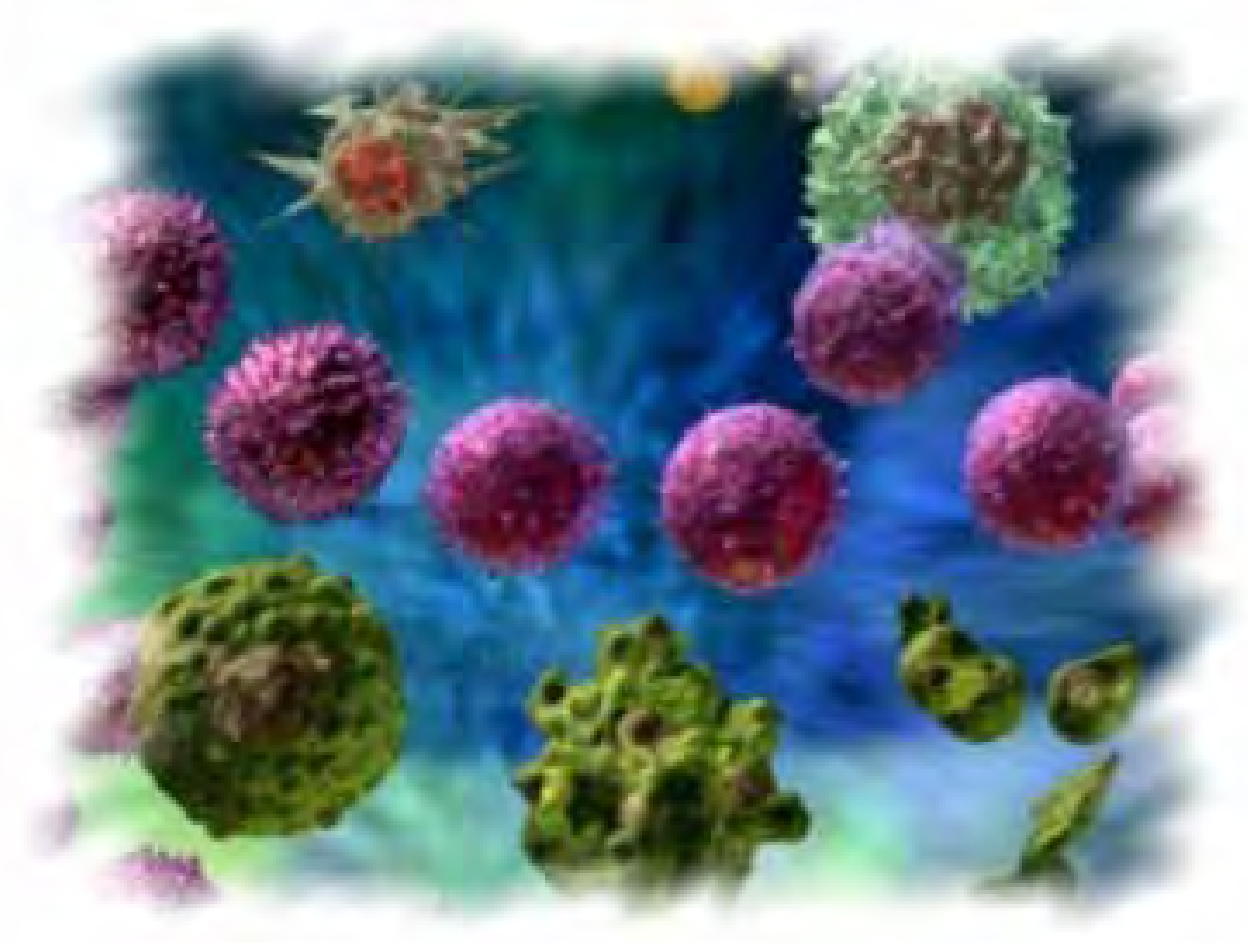

2. Clietiva 


\subsection{Objetivo geral}

Avaliar as subpopulações de linfócitos de pacientes com câncer de ovário com ênfase na resposta imune adaptativa.

\subsection{Objetivos específicos}

1. Avaliar no contexto ex-vivo as populações de linfócitos T CD4+ e CD8+ de pacientes submetidas à tratamento cirúrgico para câncer de ovário.

2. Avaliar no contexto ex-vivo as populações de linfócitos B no sangue periférico de pacientes submetidas à laparotomia. 


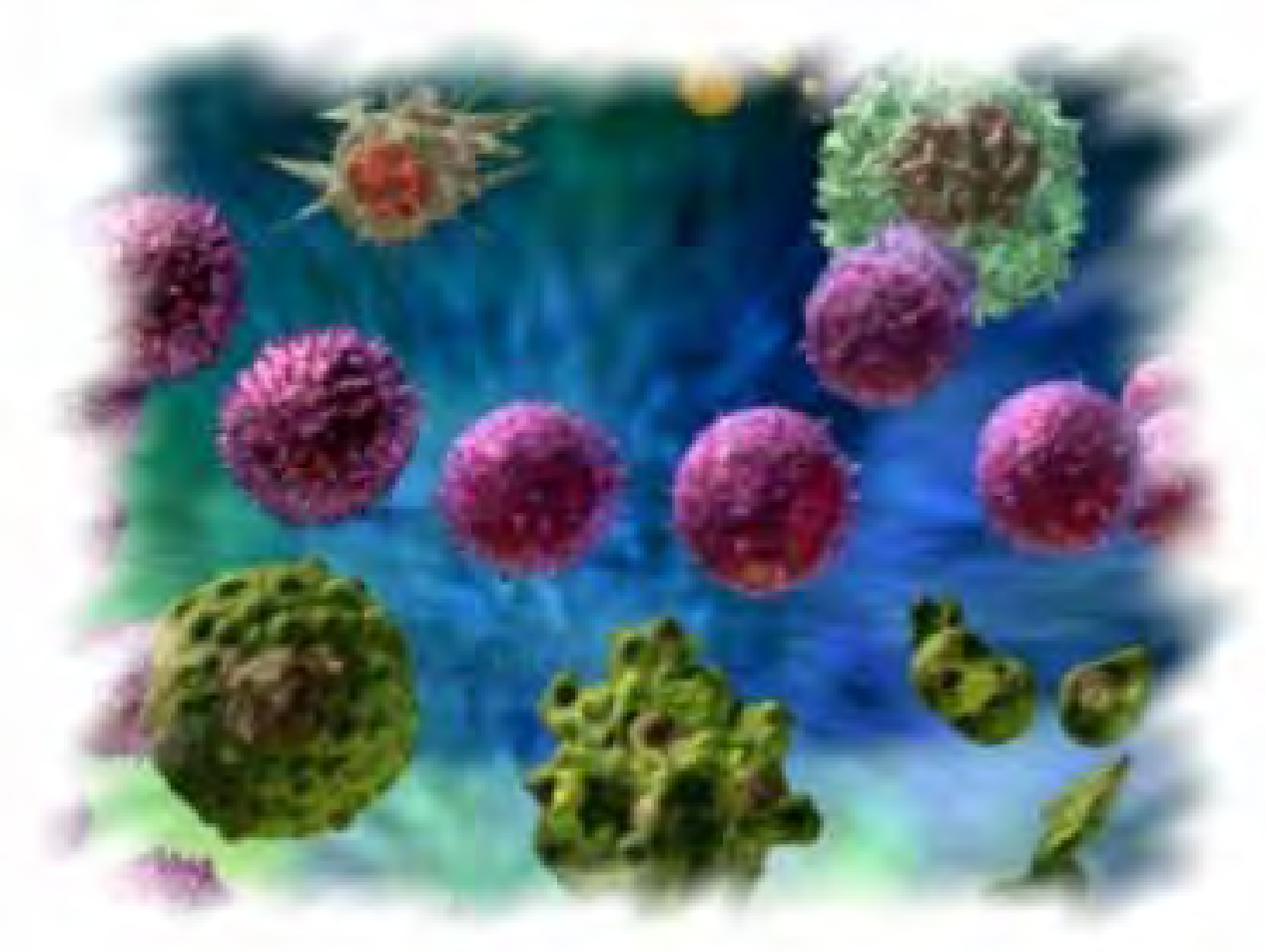

3. Casuística e Métados 


\subsection{Casuística}

Trata-se de estudo transversal onde foram avaliadas 36 mulheres atendidas nos ambulatórios de ginecologia e de oncologia ginecológica do Hospital das Clínicas da UFMG e no Hospital Mário Penna no período de setembro de 2008 a setembro de 2009. Essas mulheres procuraram os ambulatórios para realização de exame ginecológico de rotina (colpocitologia oncótica) ou foram encaminhadas para realização de propedêutica de massa pélvica. Todas as pacientes foram submetidas a exame clínico, ginecológico e ultrassonografia transvaginal.

O tratamento com laparotomia foi indicado para aquelas mulheres que apresentavam massa pélvica com indicação de ressecção cirúrgica e as peças cirúrgicas foram avaliadas pelo serviço de anatomia patológica de referência de cada hospital. As pacientes selecionadas foram agrupadas em 3 grupos de acordo com os achados ultrassonográficos e exame anatomopatológico da peça cirúrgica: controle (sem evidência de massa pélvica ao ultrassom), neoplasia ovariana benigna (cistadenoma seroso de ovário) e neoplasia ovariana maligna (cistoadenocarcinoma de ovário).

O estudo foi aprovado pelo Comitê de Ética em Pesquisa da Universidade Federal de Minas Gerais sob o parecer de n. ETIC 326/08 (anexo I). 


\subsection{1 - Critérios de Inclusão}

$\checkmark \quad$ Mulheres com diagnóstico de cistoadenocardinoma seroso de ovário submetidas a tratamento cirúrgico;

$\checkmark$ Mulheres com diagnostico de cistoadenoma de ovário submetidas a tratamento cirúrgico;

$\checkmark \quad$ Mulheres sem evidências de doenças ginecológicas ou neoplasias malignas;

$\checkmark$ Ausência de processo infeccioso agudo peritoneal evidente à laparotomia;

$\checkmark$ Pacientes sem tratamento prévio por quimioterapia e/ou radioterapia;

$\checkmark$ Não utilização de imunossupressores, corticosteróides e/ou antiinflamatórios não esteróides há pelo menos 3 meses;

$\checkmark \quad$ Termo de consentimento livre e esclarecido assinado. 


\subsection{Método}

A avaliação por citometria de fluxo (CMF) foi realizada em amostras de sangue periférico, obtidas através de punção venosa, utilizando anticoagulante EDTAK3 (ácido etileno-diamino tetracético) 1,5 +/- 0,15 $\mathrm{mg} / \mathrm{mL}$ preparadas por técnica de marcação direta e "Iyse/wash". A análise por CMF foi realizada através da utilização de 5 parâmetros: tamanho celular (FSC), complexidade interna (SSC) e três fluorescências: FITC, PE e TC. O painel de anticorpos monoclonais inclui os seguintes marcadores: CD4, CD8, HLA-DR, CD54, CD62L, CD18, CCR2, CXCR4, CCR5, CCR3, CXCR3, CD25, CD5, CD69, CD19, CD23, e controle isotípico. Todos os resultados de imunofenotipagem encontram-se armazenados no Laboratório de Biomarcadores de Diagnóstico e Monitoração do Centro de Pesquisa René Rachou.

\subsubsection{Análise por Citometria de Fluxo - Protocolo de imunofenotipagem celular}

Foram coletados no pré-operatório, antes da indução anestésica, sangue periférico em tubos a vácuo de $5 \mathrm{~mL}$, contendo anticoagulante EDTA-K3 (Vacutainer - Becton Dickinson -BD, E.U.A.), para a realização dos ensaios no contexto ex vivo de imunofenotipagem dos linfócitos. Logo após a coleta do sangue, os tubos foram invertidos 4 a 6 vezes para a homogeneização perfeita, e armazenados em temperatura ambiente $\left(20\right.$ a $\left.25^{\circ} \mathrm{C}\right)$. 
Em tubos de poliestireno $12 \times 75 \mathrm{~mm}$, foram adicionados $2 \mu \mathrm{L}$ do anticorpo monoclonal específico para o marcador de superfície celular de interesse marcado com fluorocromo (Tabela 1). Combinações específicas de anticorpos monoclonais marcados com fluorocromos (Isoticianato de fluoresceína - FITC; Ficoeritrina - PE; Cychrome - CYCHR; Tricolor - TC) distintos foram utilizadas para a análise simultânea de marcadores de superfície celular necessários para a caracterização de subpopulações celulares de interesse. Para cada combinação de anticorpos monoclonais, foram adicionadas alíquotas de $50 \mu \mathrm{L}$ de sangue periférico. Após homogeneização em vórtex, as preparações foram incubadas por 30 minutos, à temperatura ambiente e ao abrigo da luz. Após o período de incubação, as amostras foram submetidas à lise dos eritrócitos, utilizando $2 \mathrm{~mL}$ de solução de lise comercial (FACS® Lysing Solution - Becton Dickinson) diluída 10 vezes em água destilada. Após nova homogeneização em vórtex, as preparações foram incubadas por 10 minutos a temperatura ambiente e então submetidas à centrifugação (1300rpm, 7 minutos a $\left.18^{\circ} \mathrm{C}\right)$. $\mathrm{O}$ sobrenadante foi descartado e os leucócitos lavados com $2 \mathrm{~mL}$ de PBS $(0,015 \mathrm{M}$ pH 7,4), empregando-se as mesmas condições de centrifugação anteriormente citadas. Numa etapa final, os leucócitos foram fixados com $200 \mu \mathrm{L}$ de solução fixadora $(10 \mathrm{~g} / \mathrm{L}$ de paraformaldeído, $1 \%$ de cacodilato de sódio, 6,65g/L de cloreto de sódio, $\mathrm{pH} 7,2$ ). Após um período de pelo menos 15 minutos a $4^{\circ} \mathrm{C}$, os parâmetros fenotípicos e morfométricos das células presentes em cada tubo foram determinados no citômetro de fluxo (FACScalibur® - Becton Dickinson). Foram coletados vinte mil eventos para a análise ex vivo das amostras. 0 programa CELLQuest $\circledast$ foi utilizado para a aquisição de dados e para a análise 
dos resultados foi empregado o programa FlowJo versão 7.5.5 para Windows

XP (@Tree Star, Inc. 2009) associando diferentes estratégias (Figura 1).

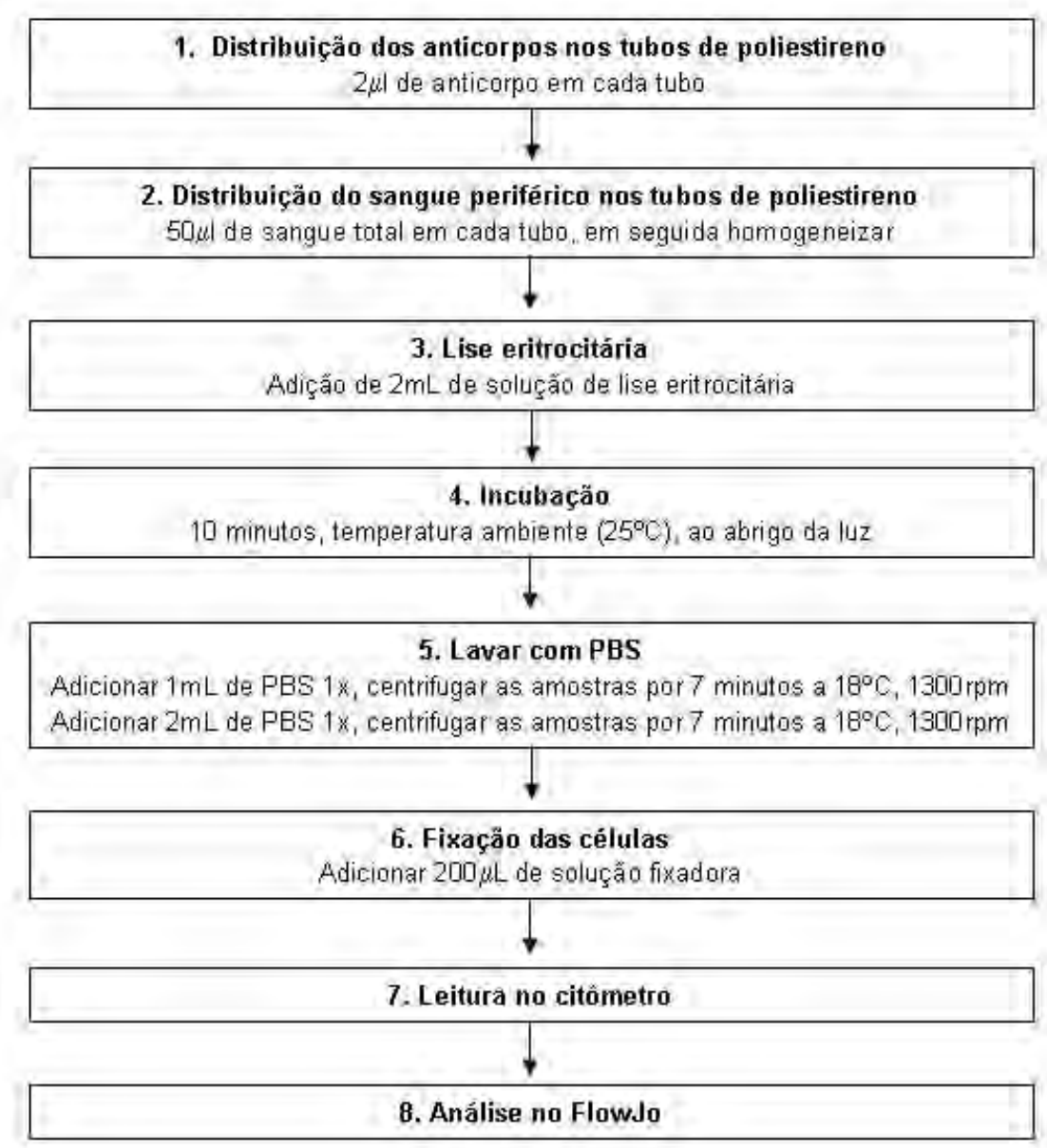

Figura 1: Fluxograma do protocolo básico de Imunofenotipagem para detecção das células do sangue periférico marcados com as combinações específicas de anticorpos monoclonais marcados com fluorocromos.

Tabela 1: Anticorpos monoclonais marcados com fluorocromos utilizados para análise de populações, subpopulações celulares e moléculas de superfície.

\begin{tabular}{|c|c|c|c|}
\hline \multicolumn{1}{c}{ Anticorpo } & Fluocr. $^{*}$ & {[]$^{* *}$} & Fenótipo alvo no estudo $^{*}$ \\
\hline Anti-IgG1 & FITC & $0,5 \mu \mathrm{g}$ & Controle isotípico \\
\hline Anti-lgG1 & PE & $0,5 \mu \mathrm{g}$ & Controle isotípico \\
\hline Anti-lgG1 & PerCP & $0,5 \mu \mathrm{g}$ & Controle isotípico \\
\hline Anti-lgG2a & PE & $0,5 \mu \mathrm{g}$ & Controle isotípico \\
\hline Anti-CCR2 & FITC & $0,5 \mu \mathrm{g}$ & $\begin{array}{c}\text { Migração de linfócitos T, monócitos, basófilos, eosinófilos, } \\
\text { células dendríticas. Liga-se a CCL2 (MCP-1), CCL7 (MCP- } \\
\text { 3), CCL8 (MCP-2), CCL12 (MCP-5), CCL13 (MCP-4), } \\
\text { CCL16 (HCC-4). }\end{array}$ \\
\hline Anti-CCR3 & FITC & $0,5 \mu \mathrm{g}$ & $\begin{array}{c}\text { Migração de eosinófilos, basófilos, mastócitos, linfócitos T. } \\
\text { Liga-se a CCL5 (RANTES), CCL7 (MCP-3), CCL8 (MCP- }\end{array}$ \\
\hline
\end{tabular}




\begin{tabular}{|c|c|c|c|}
\hline & & & 2), CCL11 (EOTAXINA). \\
\hline Anti-CCR5 & FITC & $0,5 \mu \mathrm{g}$ & 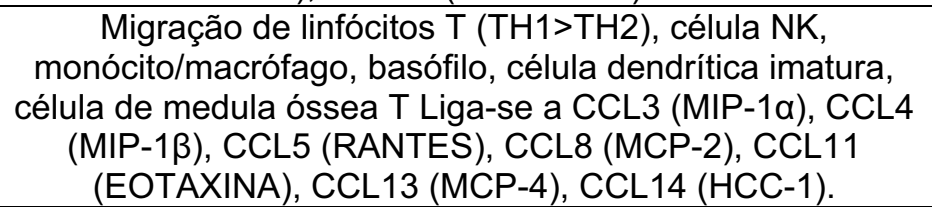 \\
\hline Anti-CD18 & $\mathrm{PE}$ & $0,5 \mu \mathrm{g}$ & Molécula de adesão celular expressa em leucócitos. \\
\hline Anti-CD19 & TC & $0,5 \mu \mathrm{g}$ & Células B \\
\hline Anti-CD23 & $\mathrm{PE}$ & $0,5 \mu \mathrm{g}$ & $\begin{array}{c}\text { Molécula de ativação celular, receptor de baixa afinidade } \\
\text { de IgE (Fc\&RII). Células B maduras, macrófagos ativados, } \\
\text { eosinófilos }\end{array}$ \\
\hline Anti-CD25 & $\mathrm{PE}$ & $0,5 \mu \mathrm{g}$ & $\begin{array}{c}\text { Ativação de leucócitos, identificação de células T } \\
\text { reguladoras. }\end{array}$ \\
\hline Anti- & TC & $0,5 \mu \mathrm{g}$ & $\begin{array}{l}\text { Associado ao receptor de células T (TCR). Exigido para } \\
\text { expressão na superfície celular e para transdução de sinal } \\
\text { pelo TCR. Expresso em timócitos e linfócitos T. }\end{array}$ \\
\hline Anti-CD4 & FITC & $0,5 \mu \mathrm{g}$ & $\begin{array}{l}\text { Co-receptor para moléculas do complexo de } \\
\text { histocompatibilidade principal de classe II. }\end{array}$ \\
\hline Anti-CD4 & $\mathrm{PE}$ & $5 \mu \mathrm{g}$ & Células $\mathrm{T}_{\mathrm{H}} 1$ e $\mathrm{T}_{\mathrm{H}} 2$, monócitos, macrófagos \\
\hline Anti-CD5 & FITC & $0,5 \mu \mathrm{g}$ & Células $T$, subgrupo de células $B$. \\
\hline Anti-CD54 & $\mathrm{PE}$ & $0,5 \mu \mathrm{g}$ & $\begin{array}{c}\text { Molécula de adesão de leucócitos. Liga-se à CD11a/CD18. } \\
\text { Células hematopoiéticas e não-hematopoiéticas }\end{array}$ \\
\hline $\begin{array}{l}\text { Anti- } \\
\text { CD62L }\end{array}$ & $\mathrm{PE}$ & $0,5 \mu \mathrm{g}$ & $\begin{array}{c}\text { Molécula de adesão celular expressa em leucócitos. } \\
\text { Células B e T, monócitos, células NK }\end{array}$ \\
\hline Anti-CD69 & $\overline{P E}$ & $0,5 \mu \mathrm{g}$ & $\begin{array}{c}\text { Molécula de ativação de leucócitos: células T e B ativadas, } \\
\text { macrófagos ativados, células NK. }\end{array}$ \\
\hline Anti-CD8 & TC & $0,5 \mu \mathrm{g}$ & $\begin{array}{c}\text { Co-receptor para MHC de classe I. Expresso em subgrupos } \\
\text { de timócitos e linfócitos T citotóxicos. }\end{array}$ \\
\hline $\begin{array}{c}\text { Anti- } \\
\text { CXCR4 }\end{array}$ & FITC & $0,5 \mu \mathrm{g}$ & $\begin{array}{c}\text { Célula de medula óssea CD34+, linfócito progenitor, célula } \\
\text { T, célula dendrítica, célula B, célula plasmática, célula T } \\
\text { CD4 ativada }\end{array}$ \\
\hline $\begin{array}{l}\text { Anti-HLA- } \\
\text { DR }\end{array}$ & $\mathrm{PE}$ & $0,5 \mu \mathrm{g}$ & $\begin{array}{c}\text { Molécula de MHC de classe II expressa na superfície de } \\
\text { células humanas.Linfócito T ativado, monócito pró- } \\
\text { inflamatório }\end{array}$ \\
\hline $\begin{array}{l}\text { Anti- } \\
\text { CXCR3 }\end{array}$ & FITC & $0,5 \mu \mathrm{g}$ & $\begin{array}{c}\text { Migração de fibroblastos e linfócitos T ativados (TH1>TH2). } \\
\text { Liga-se a CXCL4 (PF4), CXCL9 (Mig), CXCL10 (IP-10), } \\
\text { CXCL11 (I-TAC). }\end{array}$ \\
\hline
\end{tabular}

Fonte: CD Reference Chart. 8th HLDA International Workshop, 2004. MASON et al., 2003; D'AMBROSIO et al., 2003; ONO et al., 2003.

FITC = isotiocianato de fluoresceína; $\mathrm{PE}=$ ficoeritrina; $\mathrm{TC}=$ tricolo

* Fluocr. = Fluocromo

**[ ] = Concentração

A identificação da população de linfócitos e a determinação do valor percentual de marcadores de superfície e receptores de quimiocinas foram realizadas através de um sistema de computador acoplado ao citômetro. A aquisição dos dados foram realizadas em citômetro de fluxo FACSCalibur ${ }^{\mathrm{TM}}$, programa CellQuest, equipado com um laser de argônio de $488 \mathrm{~nm}$ e outro de $625 \mathrm{~nm}$. 
Pela análise gráfica de tamanho e complexidade interna, avaliou-se a população leucocitária total, como demonstrado na figura 2, onde Linf corresponde à população de linfócitos, Mon corresponde à população de monócitos e Gran à de granulócitos.

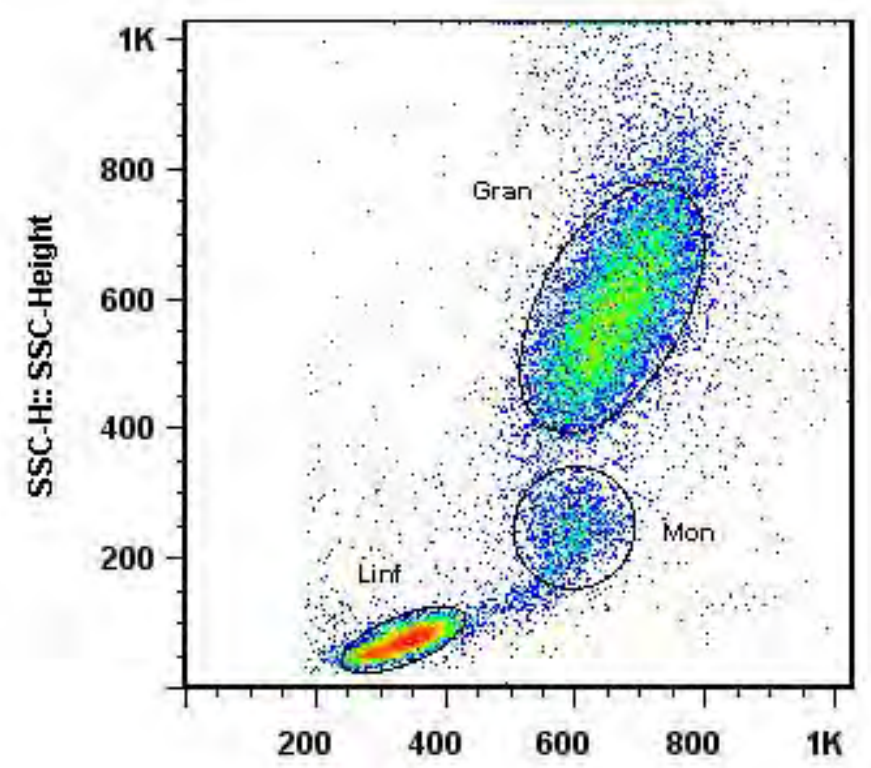

FSC-H:: FSC-Height

Figura 2. Distribuição gráfica das populações celulares segundo os parâmetros de tamanho (FSC - Forward Scatter) e de complexidade interna das células (SSC - Side Scatter) onde Linf corresponde à população de linfócitos, Mon corresponde à população de monócitos e Gran corresponde à população de granulócitos.

A população de interesse (linfócitos) foi selecionada sob a forma de "gate" como mostrado na figura 3, e analisada nos gráficos do tipo "dot plot" e/ou "pseudocolor", procurando-se correlacionar todas as fluorescências entre si. Esta análise possibilitou o maior número possível de informações para cada marcador imunofenotípico, como exemplificado na figura 4 , onde foram obtidos resultados em números percentuais para cada marcador imunofenotípico correspondente à localização das populações devidamente marcadas nos 
quadrantes dos gráficos do tipo "pseudocolor". Para a obtenção dos valores de linfócitos T, utilizou-se da estratégia do somatório do percentual de linfócitos T CD4+ e linfócitos T CD8+, como ilustra a figura 5. Estes valores percentuais foram obtidos de tabelas de análise estatística para os respectivos quadrantes através do programa FlowJo.

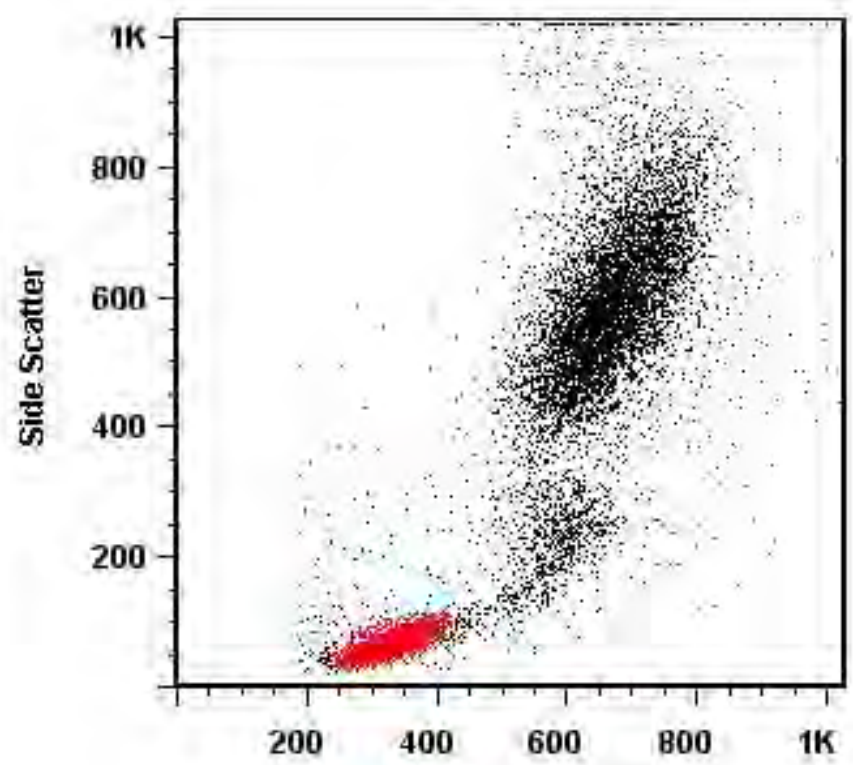

Forward Scatter

Figura 3. Distribuição gráfica das populações celulares segundo os parâmetros de tamanho (FSC - Forward Scatter) e de complexidade interna das células (SSC - Side Scatter) mostrando em vermelho a população de linfócitos selecionada sob a forma de "gate". 


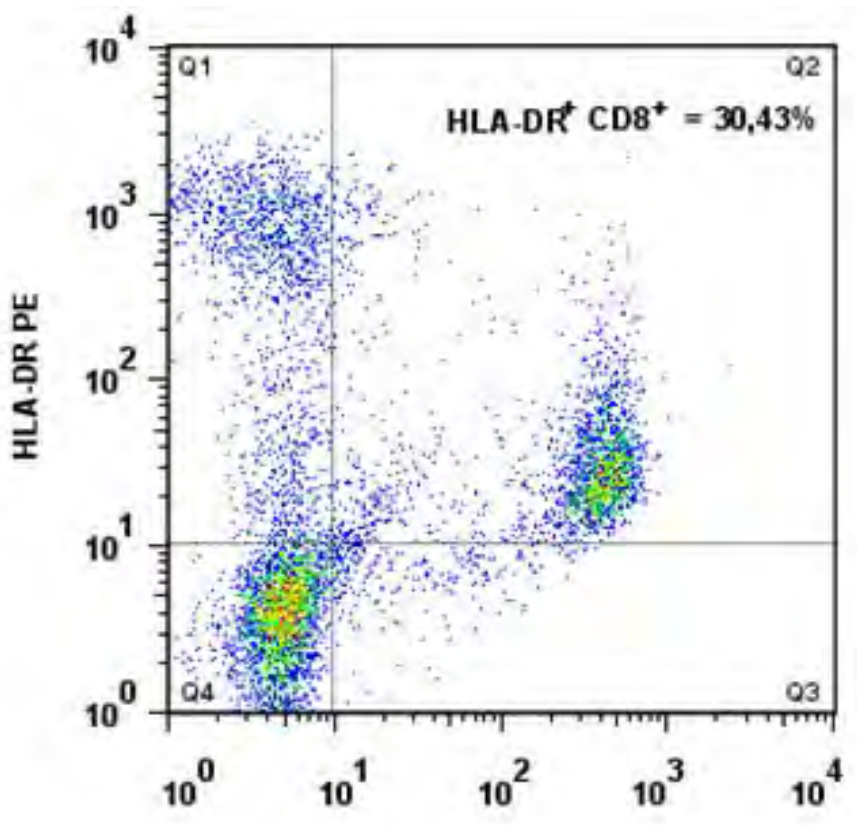

\section{CDE TC}

Figura 4. Gráfico do tipo "pseudocolor" mostrando no quadrante superior a esquerda (Q1) a população positiva para HLA-DR e negativa para CD8, no quadrante superior à direita (Q2) a população duplamente positiva para HLA-DR e CD8, no quadrante inferior à direita (Q3) a população positiva para CD8 e no quadrante inferior à esquerda $(\mathrm{Q} 4)$ a população duplamente negativa para HLA-DR e CD8.

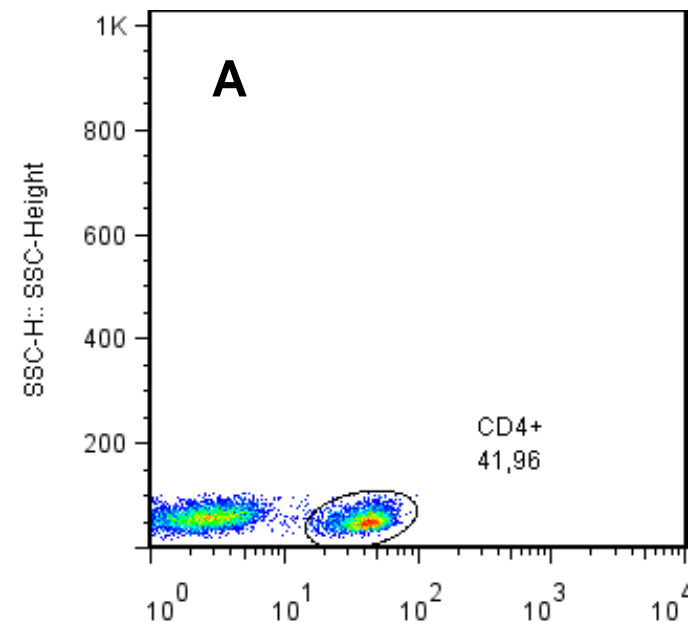

FL1-H:: CD4

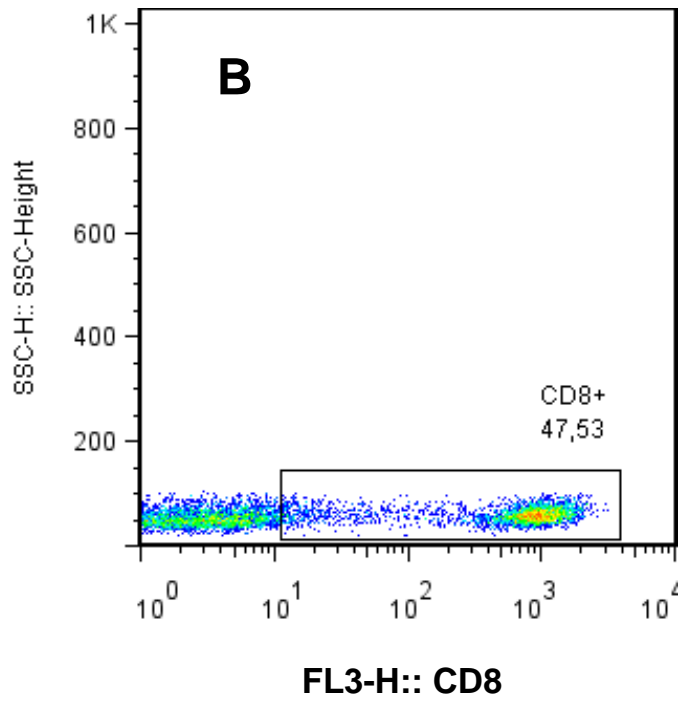

Figura 5. Gráfico do tipo "pseudocolor" de subpopulações de linfócitos obtidos por citometria de fluxo. (A) representa no "gate" selecionado CD4+ de fluorescência 1 (FL1-H: CD4) versus granulosidade (SSC-H: SSC-Height) a população de linfócitos positiva para CD4. (B) representa no "gate" selecionado CD8+ de fluorescência 3 (FL3-H: CD8) versus granulosidade (SSC-H: SSC-Height) a população de linfócitos positiva para CD8. O Somatório destas populações foi considerado como a população de linfócitos $T$. 


\subsubsection{Aspectos éticos e legais}

O protocolo da presente pesquisa, bem como o Termo de Consentimento Livre

e Esclarecido, apresentados e aprovados pelo Departamento de Ginecologia e Obstetrícia da Faculdade de Medicina da Universidade Federal de Minas Gerais, foram aprovados pela Comissão de Ética em Pesquisa da Universidade Federal de Minais Gerais (Anexo I e II). Os doadores foram esclarecidos sobre o protocolo de pesquisa e assinaram o Termo de Consentimento Livre e Esclarecido.

\subsubsection{Análise Estatística}

As informações foram codificadas e digitadas em banco de dados no programa GraphPad Prism para Windows versão 5.00 (GraphPad Software, Inc.), que desenvolveu os cálculos posteriores. Foi avaliado o pressuposto de normalidade e com este objetivo aplicou-se o teste de Kolmogorov-Simirnov que indicou que a distribuição das dosagens séricas dos marcadores avaliados não seguem a normalidade $(p<0,001)$. Portanto, nesta análise foram empregados testes não paramétricos, que são mais robustos a violação deste pressuposto. As diferenças entre os grupos foram avaliadas pelo teste de Mann-Whitney (dois grupos) ou Kruskal-Walis (três grupos) conforme indicados. As diferenças com valor de $p<0,05$ foram consideradas significativas. 


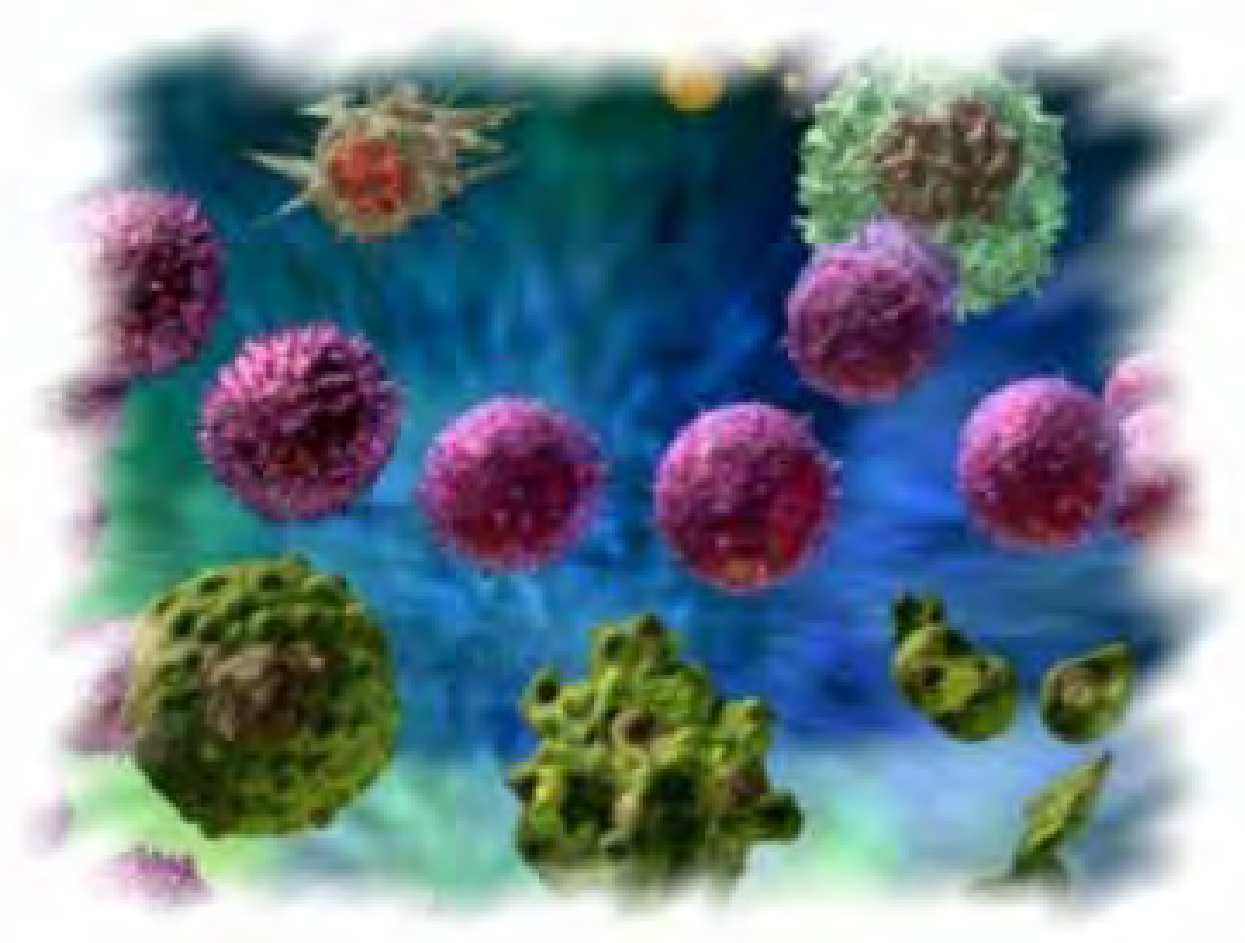

4. Resultados 


\subsection{Características gerais da amostra}

As pacientes incluídas neste estudo apresentaram idade média \pm de 51,67 com erro padrão de $\pm 2,8$ anos e variação entre 19 e 86 anos. A paridade média foi de 2,6士0,6 partos com variação entre 0 e 11 partos. O estadiamento (FIGO) das pacientes com câncer de ovário foi de três mulheres com estadio IA $(17,6 \%)$, uma paciente com estadio IC $(5,9 \%), 12$ casos com estadio IIIC $(70,6 \%)$ e uma paciente com estadio IV $(5,9 \%)$

\subsection{Análise ex vivo da porcentagem de linfócitos T (CD4+ e CD8+), linfócitos T auxiliares (CD4+) e linfócitos T citotóxicos (CD8+) do sangue periférico de mulheres do grupo controle, neoplasia benigna e maligna.}

Foi realizado, nesse estudo, a análise do percentual de linfócitos $\mathrm{T}$ e suas subpopulações no sangue periférico de pacientes hígidas, pacientes com tumor benigno e pacientes com câncer de ovário empregando ensaios de dupla marcação associado a estratégia de análise convencional, como descrito na metodologia.

Os resultados do percentual de linfócitos $T\left(C D 4^{+}\right.$e $\left.C D 8^{+}\right)$na população de linfócitos totais do sangue periférico estão representados na Figura 6A. A análise dos dados não identificou diferença significativa na comparação entre os grupos de mulheres com tumor benigno em relação ao grupo controle e entre o grupo de tumor benigno e câncer de ovário. Entretanto, a análise dos resultados mostrou diminuição estatisticamente significativa $(p<0,05)$ da porcentagem de células T do grupo de mulheres com câncer de ovário quando 
comparado ao grupo controle. Em relação ao percentual de linfócitos T dos três grupos, foi observada diferença estatisticamente significativa $(p=0,0020)$.

A análise da razão entre linfócitos $T\left(C D 4^{+} / C D 8^{+}\right)$circulantes no sangue periférico revelou que não houve diferença significativamente significativa entre os grupos $(p=0,4489)$. A análise entre os grupos mostrou que o grupo TB e CA Ovário apresentam um valor da mediana da razão de linfócitos $T$ circulantes maiores em relação ao grupo CT. Nenhuma diferença significativa foi observada entre os grupos (Figura 6B).

A Figura $6 \mathrm{C}$ e $6 \mathrm{D}$ mostra os resultados do percentual de linfócitos $\mathrm{T} C \mathrm{CD} 4^{+}$e $\mathrm{T}$ $\mathrm{CD}^{+}$na população de linfócitos totais do sangue periférico de mulheres hígidas, mulheres com tumor benigno e câncer de ovário.. A análise dos resultados mostrou que o percentual de linfócitos $\mathrm{T} \mathrm{CD}^{+}$apresentou diferenças significativas entre os grupos $(p=0,0399)$. Entretanto a população de linfócitos $\mathrm{T} \mathrm{CD8}^{+}$não apresentou diferenças significativas $(p=0,2939)$. Nenhuma diferença significativa foi observada entre os grupos, quando comparados dois a dois, em relação ao marcador $\mathrm{CD}^{+}$e $\mathrm{CD}^{+}$para os linfócitos. 
A

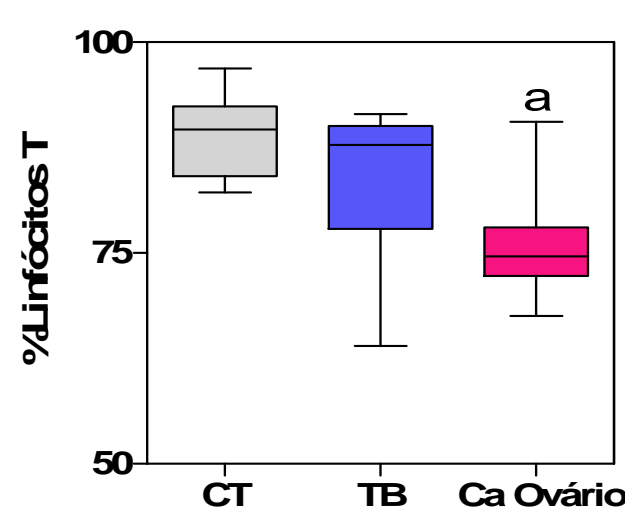

C

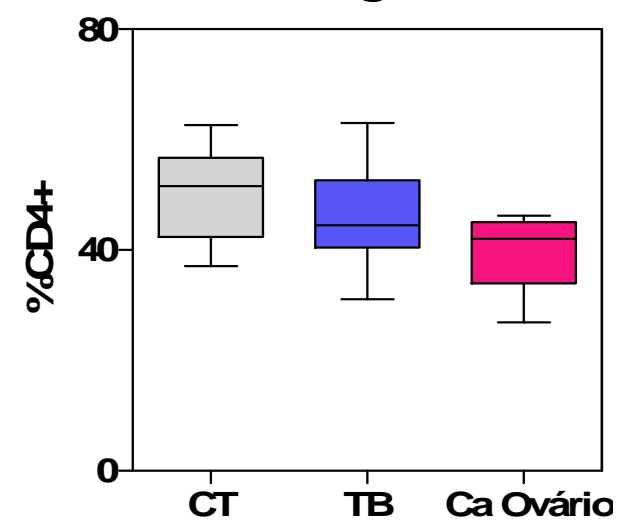

B

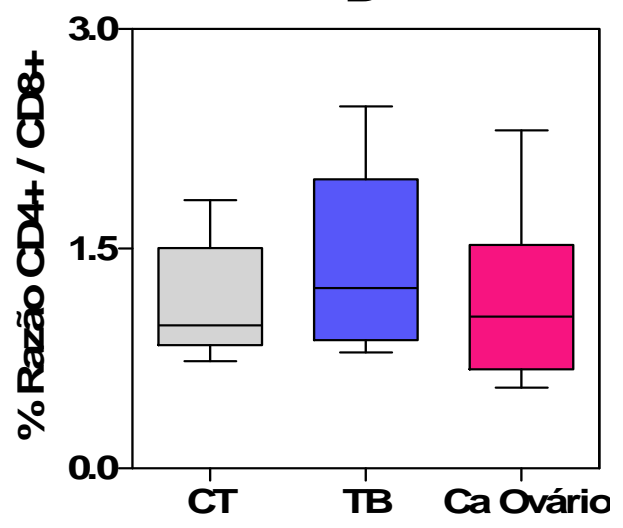

$\mathrm{D}$

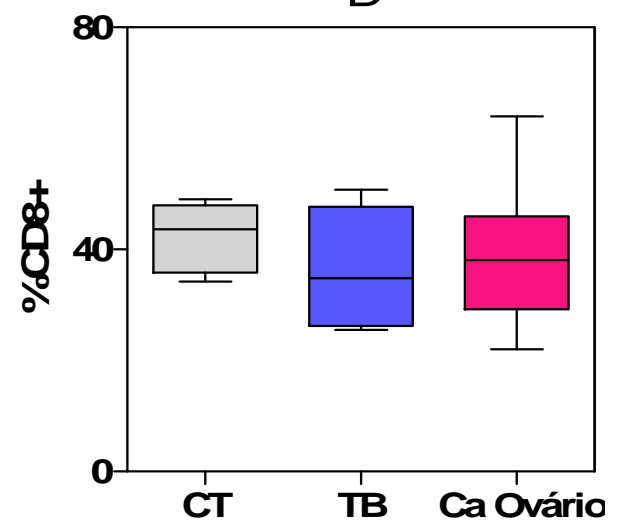

Figura 6: Linfócitos T (CD4+ e CD8+) (A), porcentagem de linfócitos T auxiliares (CD4+) em relação a linfócitos $T$ citotóxicos $(C D 8+)(B)$, linfócitos $T$ auxiliares $(C D 4+)(C)$ e linfócitos $T$ citotóxicos $(C D 8+)(C)$ do sangue periférico de indivíduos saudáveis $(C T=10)$, pacientes com tumor benigno de ovário $(T B=09)$ e câncer de ovário $($ Ca Ovário $=17)$. Os resultados estão apresentados como porcentagem de linfócitos $\mathrm{T}$, expressando os marcadores de superfície avaliados, em formato de gráficos de boxes que destacam os valores: mínimo, $25 \%, 50 \%$ mediana, $75 \%$ e máximo. As diferenças entre os grupos foram avaliadas pelo teste de KruskalWallis (3 grupos ) ou Mann-Whitney (2 grupos). A diferença estatisticamente significativa $(p<0,05)$ entre o grupo CT e Ca Ovário está representa pelas letras a.

( $A$, $p=0,0020)$ - CT vs. TB: $p>0,05$; CT vs. Ca Ovário: $p<0,05$; TB vs. Ca Ovário: $p>0,05$;

( $B$, $p=0,0399$ ) - CT vs. TB: $p>0,05$; CT vs. Ca Ovário: $p>0,05$; TB vs. Ca Ovário: $p>0,05$;

(C , $p=0,2939)$ - CT vs. TB: $p>0,05$; CT vs. Ca Ovário: $p>0,05$; TB vs. Ca Ovário: $p>0,05$;

( $D$, $p=0,4489)$ - CT vs. TB: $p>0,05$; CT vs. Ca Ovário: $p>0,05$; TB vs. Ca Ovário: $p>0,05$. 


\subsection{Análise ex vivo da porcentagem de linfócitos B (CD19+) do sangue} periférico de mulheres do grupo controle, neoplasia benigna e maligna.

Os resultados do percentual de linfócitos $B\left(C D 19^{+}\right)$na população de linfócitos totais do sangue periférico estão representados na Figura 7. A análise dos dados identificou diferença significativa na comparação entre os grupos $(p=0,0463)$. Nenhuma diferença significativa foi observada entre os grupos, quando comparados dois a dois, em relação ao marcador $\mathrm{CD}_{1} 9^{+}$para os linfócitos B. Foi observada uma diminuição do percentual de células B dos grupos de mulheres com tumor benigno e câncer de ovário em relação ao grupo controle, quando analisado a mediana dos mesmos.

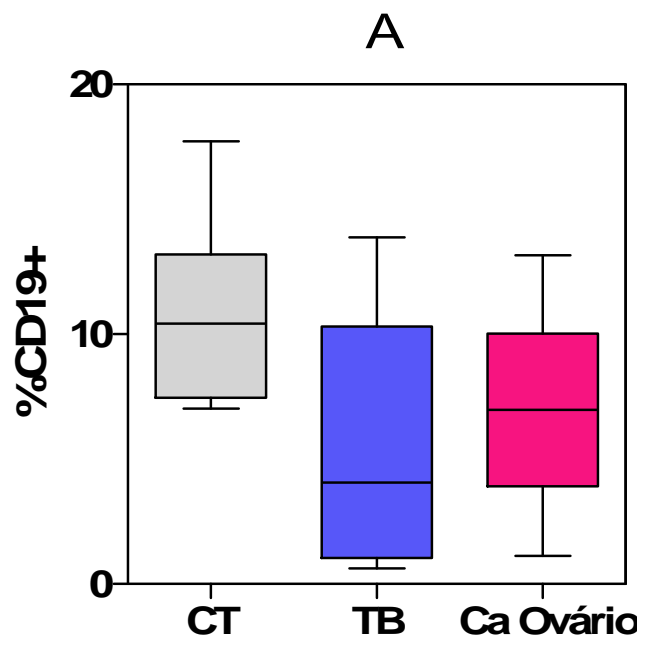

Figura 7: Linfócitos B (CD19+) do sangue periférico de indivíduos saudáveis $(C T=10)$, pacientes com tumor benigno de ovário $(T B=09)$ e câncer de ovário $(C a$ Ovário $=17)$. Os resultados estão apresentados como porcentagem de linfócitos $\mathrm{B}$, expressando o marcador de superfície avaliado, em formato de gráfico de boxe que destaca os valores: mínimo, $25 \%, 50 \%$ mediana, $75 \%$ e máximo. As diferenças entre os grupos foram avaliadas pelo teste de KruskalWallis ( 3 grupos ) ou Mann-Whitney (2 grupos).

(A , $p=0,0463)$ - CT vs. TB: $p>0,05$; CT vs. Ca Ovário: $p>0,05$; TB vs. Ca Ovário: $p>0,05$; 


\subsection{Análise ex vivo da porcentagem de moléculas de ativação celular por linfócitos T CD4+ e T CD8+ do sangue periférico de mulheres do grupo controle, neoplasia benigna e maligna.}

Um ensaio de dupla marcação foi realizado para identificar as células $\mathrm{T} \mathrm{CD4}^{+} \mathrm{e}$ $\mathrm{T} \mathrm{CD8}^{+}$que co-expressam o marcador HLA-DR no sangue periférico de mulheres hígidas, mulheres com tumor benigno e mulheres com câncer de ovário.

A análise dos dados não mostrou diferenças estatisticamente significativas no percentual de células $C D 4^{+} H L A-D R^{+}(p=0,8008)$ e CD8 ${ }^{+} H L A-D R^{+}(p=0,4596)$. Entre os grupos de indivíduos avaliados, não foi observado diferenças estatisticamente significativas (Figura 8).

A

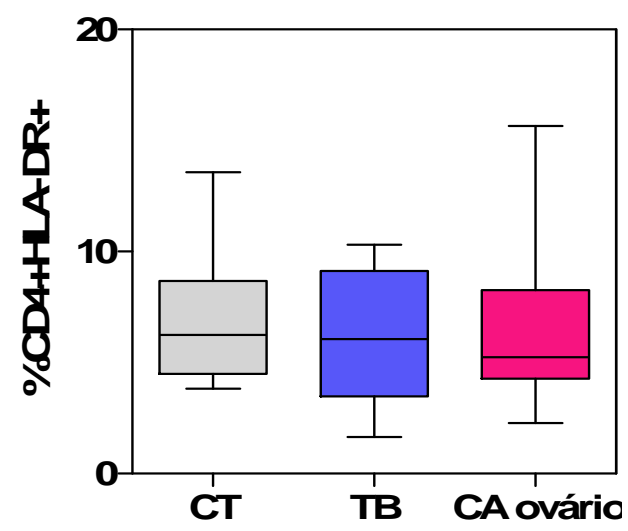

B

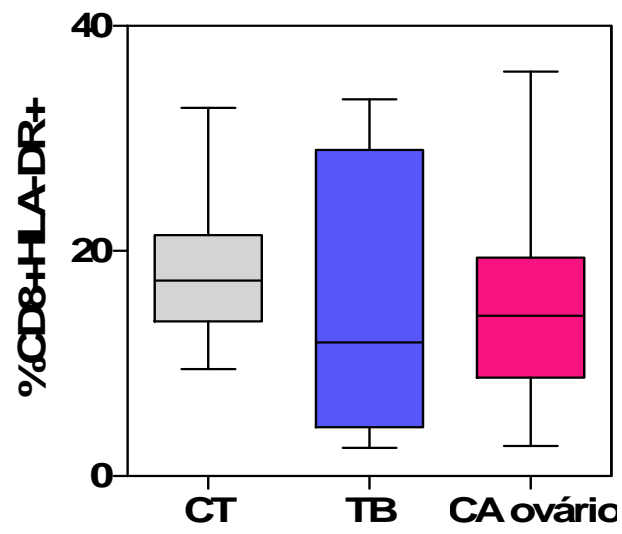

Figura 8: Linfócitos $T$ auxiliares ativados (CD4+HLA-DR+) (A) e linfócitos $T$ citotóxicos ativados $(C D 8+H L A-D R+)(B)$ do sangue periférico de indivíduos saudáveis $(C T=10)$, mulheres com tumor benigno de ovário $(T B=09)$ e câncer de ovário (Ca Ovário $=17)$. Os resultados estão apresentados como porcentagem de linfócitos TCD4+HLA-DR+ e TCD8+HLA-DR+, expressando o marcador de superfície avaliado, em formato de gráfico de boxe que destaca os valores: mínimo, 25\%, 50\%-mediana, 75\% e máximo. As diferenças entre os grupos foram avaliadas pelo teste de Kruskal-Wallis (3 grupos ) ou ou Mann-Whitney (2 grupos).

(A , $p=0,8008)$ - CT vs. TB: $p>0,05$; CT vs. Ca Ovário: $p>0,05$; TB vs. Ca Ovário: $p>0,05$;

( $B$, $p=0,4596)$ - CT vs. TB: $p>0,05$; CT vs. Ca Ovário: $p>0,05$; TB vs. Ca Ovário: $p>0,05$; 
4.5 Análise ex vivo da porcentagem de moléculas de adesão celular por linfócitos T CD4+ e T CD8+ do sangue periférico de mulheres do grupo controle, neoplasia benigna e maligna.

Dentre as moléculas de adesão celular avaliadas (CD54, CD62L, CD18) verificou-se diminuição significativa $(p<0,05)$ do número de linfócitos TCD4+ CD62L+ no grupo de mulheres com câncer de ovário quando comparado com o grupo de mulheres com tumor benigno. No grupo de mulheres com câncer de ovário foi observada diminuição significativa $(p<0,05)$ do número de linfócitos TCD8+ CD62L+ quando comparado ao grupo controle. 
A

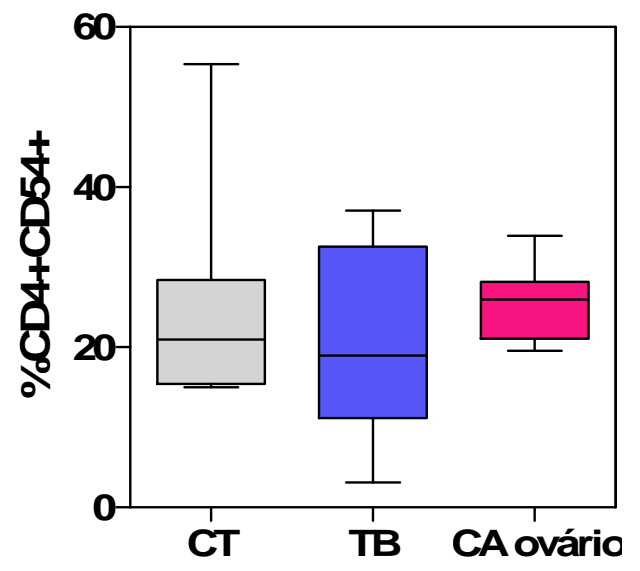

C

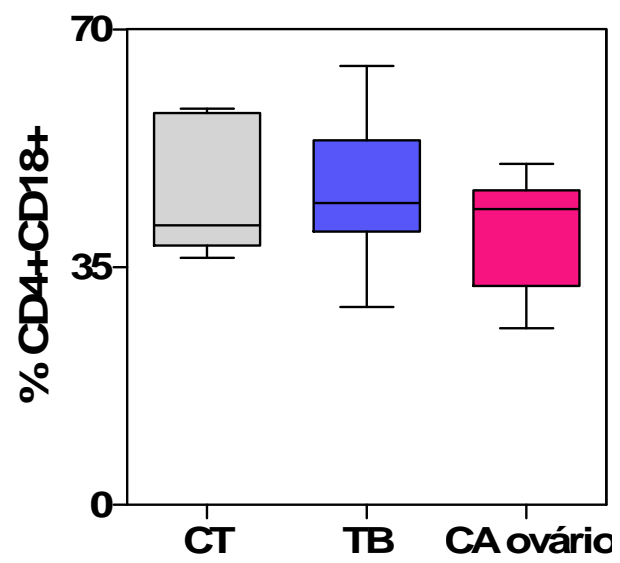

E

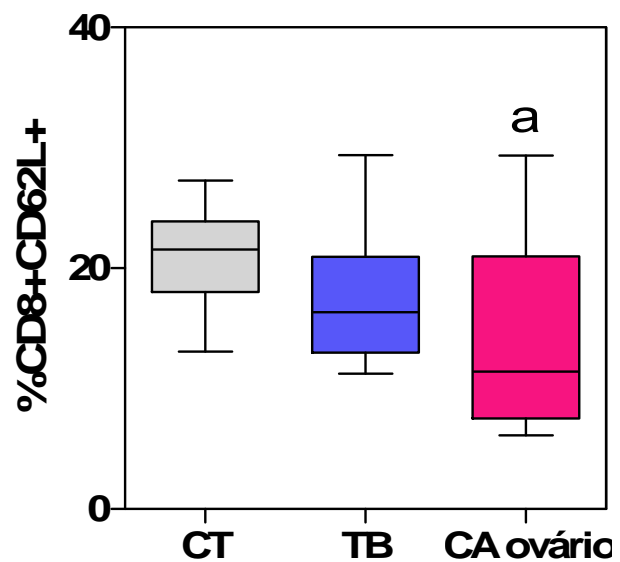

B

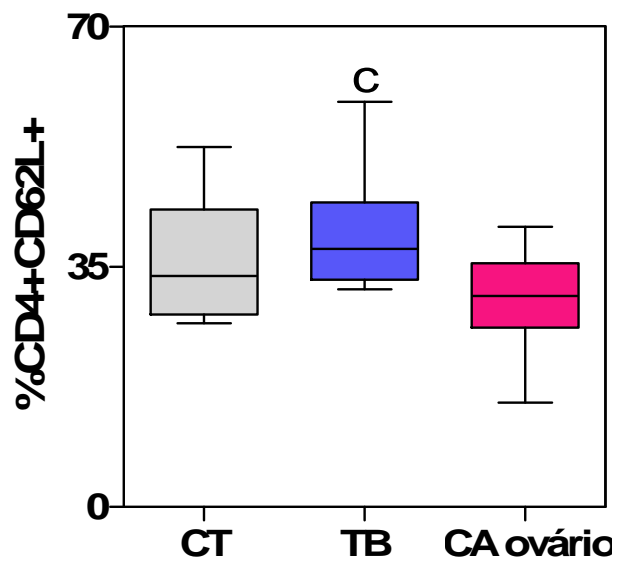

$\mathrm{D}$

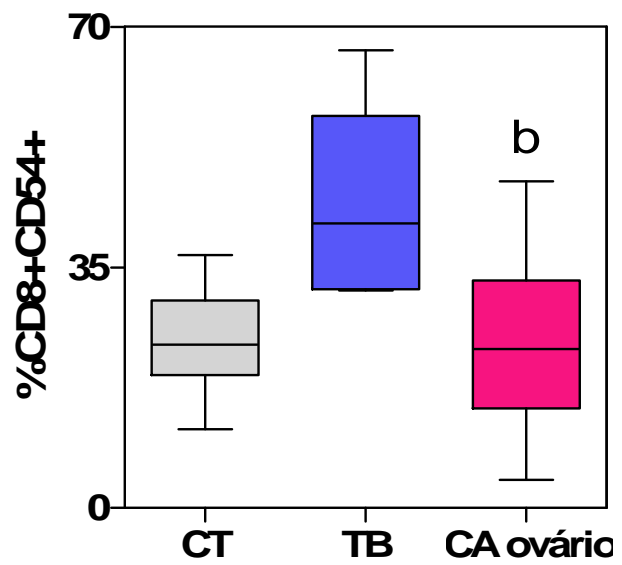

$\mathrm{F}$

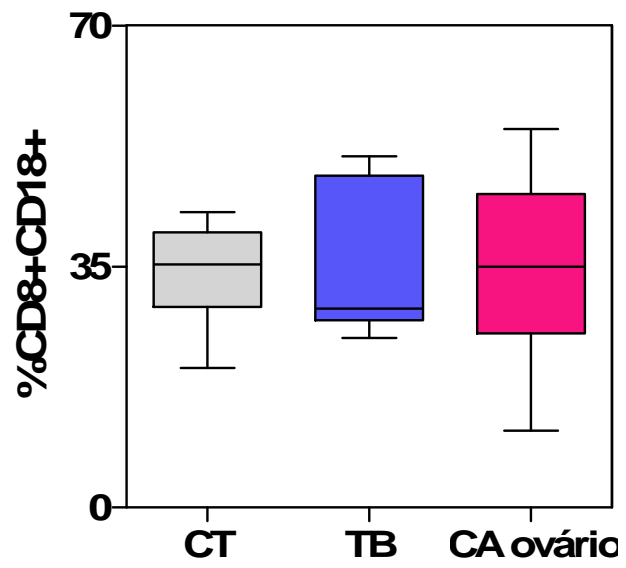

Figura 9: Número de moléculas de adesão CD54 (A e D), CD62L (B e E) e CD18 (C e F) por linfócitos T CD4+ e CD8+ do sangue periférico de mulheres saudáveis $(C T=10)$, mulheres com tumor benigno de ovário $(\mathrm{TB}=09)$ e câncer de ovário $(\mathrm{Ca}$ Ovário $=17)$. Os resultados estão apresentados como porcentagem de linfócitos TCD4+ (A, B e C) e TCD8+ (D, E e F), expressando os marcadores de superfície avaliados, em formato de gráficos de boxes que destacam os valores: mínimo, $25 \%, 50 \%$-mediana, $75 \%$ e máximo. As diferenças entre os grupos foram avaliadas pelo teste de Kruskal-Wallis ( 3 grupos ) ou Mann-Whitney (2 grupos). 
As diferenças estatisticamente significativas $(p<0,05)$ entre os grupos CT, TB e Ca Ovário estão representadas pelas letras $a, b$ e c, respectivamente.

(A , $p=0,2744)$ - CT vs. TB: $p>0,05$; CT vs. Ca Ovário: $p>0,05$; TB vs. Ca Ovário: $p>0,05$;

( $B$, $p=0,0355)$ - CT vs. TB: $p>0,05$; CT vs. Ca Ovário: $p>0,05$; TB vs. Ca Ovário: $p<0,05$;

( $C, p=0,3180$ ) - CT vs. TB: $p>0,05$; CT vs. Ca Ovário: $p>0,05$; TB vs. Ca Ovário: $p>0,05$;

( $D$, $p=0,0108)$ - CT vs. TB: $p>0,05$; CT vs. Ca Ovário: $p>0,05$; TB vs. Ca Ovário: $p<0,05$;

( $E$, $p=0,0313$ ) - CT vs. TB: $p>0,05$; CT vs. Ca Ovário: $p<0,05$; TB vs. Ca Ovário: $p>0,05$;

$(F, p=0,9931)$ - CT vs. TB: $p>0,05$; CT vs. Ca Ovário: $p>0,05$; TB vs. Ca Ovário: $p>0,05$.

\subsection{Análise ex vivo da porcentagem de linfócitos $\mathrm{T} \mathrm{CD} 4^{+} \mathrm{CD} 25^{+}$e linfócitos}

\section{T CD4 ${ }^{+} \mathrm{CD} 25^{+\mathrm{HIGH}}$ do sangue periférico de mulheres do grupo controle,}

\section{neoplasia benigna e maligna.}

A análise dos dados não mostrou diferença estatisticamente significativa do número de linfócitos T CD4 ${ }^{+} \mathrm{CD} 25^{+}$e linfócitos T CD4 ${ }^{+} \mathrm{CD} 25^{+} \mathrm{HIGH}$ (Figura 10) entre os três grupos avaliados e quando comparados dois a dois.

A

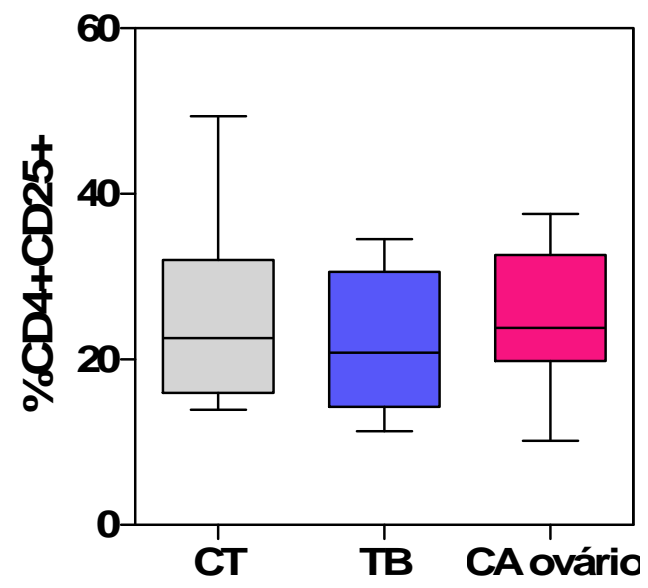

$\mathrm{B}$

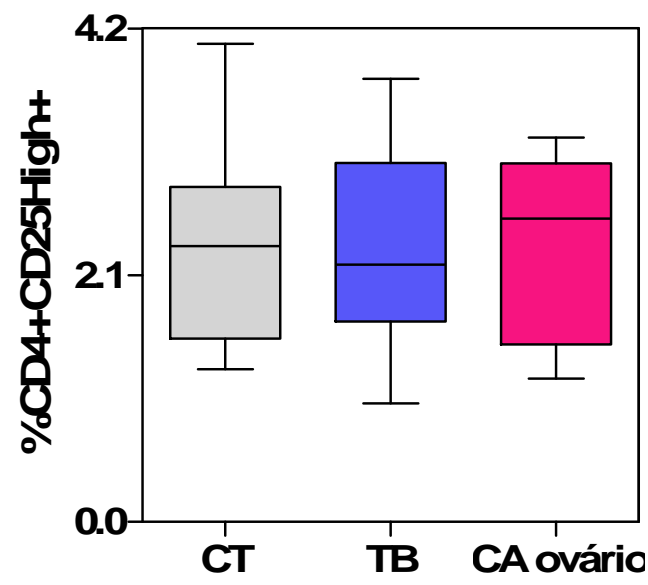

Figura 10: Linfócitos T CD4+CD25+ (A) e linfócitos T CD4+CD25+ ${ }^{\mathrm{HIH}}$ (B) do sangue periférico de mulheres saudáveis $(C T=10)$, pacientes com tumor benigno de ovário $(T B=09)$ e câncer de ovário $($ Ca Ovário $=17)$. Os resultados estão apresentados como porcentagem linfócitos TCD4+, expressando o marcador de superfície CD25 e CD25HIGH, em formato de gráficos de boxes que destacam os valores: mínimo, $25 \%, 50 \%$-mediana, $75 \%$ e máximo. As diferenças entre os grupos foram avaliadas pelo teste de Kruskal-Wallis ( 3 grupos ) ou Mann-Whitney (2 grupos).

(A , $p=0,7622)$ - CT vs. TB: $p>0,05$; CT vs. Ca Ovário: $p>0,05$; TB vs. Ca Ovário: $p>0,05$;

(B , $p=0,9719)$ - CT vs. TB: $p>0,05$; CT vs. Ca Ovário: $p>0,05$; TB vs. Ca Ovário: $p>0,05$. 


\subsection{Análise ex vivo da porcentagem de receptores de quimiocinas em linfócitos TCD4+ e TCD8+ do sangue do sangue periférico de mulheres do grupo controle, neoplasia benigna e maligna.}

Os receptores de quimiocinas possuem funções importantes que coordenam a diferenciação e o tráfego de leucócitos. Sendo assim, neste estudo foi realizada a análise do número de receptores de quimiocinas em linfócitos circulantes de mulheres do grupo controle, mulheres com tumor benigno e com câncer de ovário.

Os receptores de quimiocinas avaliados nesse estudo foram CCR2, CXCR4, CCR5, CCR3, e CXCR3 (Figura 11), que foram analisados pela porcentagem de linfócitos TCD4+ e TCD8+ positivos para esses marcadores. A análise dos resultados demonstrou aumento significativo $(p<0,05)$ do número de linfócitos $T$ CD4+CCR3+ (Figura 11E) do grupo Ca Ovário quando comparado ao grupo controle. Em relação aos marcadores CCR2+ e CCR5+ para a marcação dos linfócitos TCD8+ foi observado um aumento estatisticamente significativo $(p<0,05)$ (Figura 23F e 23H) do grupo Ca de Ovário quando comparado com o grupo de mulheres com tumor benigno e com o grupo controle, respectivamente. Não foram observadas diferenças estatisticamente significativas entre os demais grupos para os marcadores em questão, quando comparados dois a dois. Foi possível observar diferença estatisticamente significativa entre os grupos CD8+CCR2+ $(p=0,0294), C D 8+C C R 5+(p=0,0216)$ e CD4+CCR3+ $(p=0,0233)$. 
A

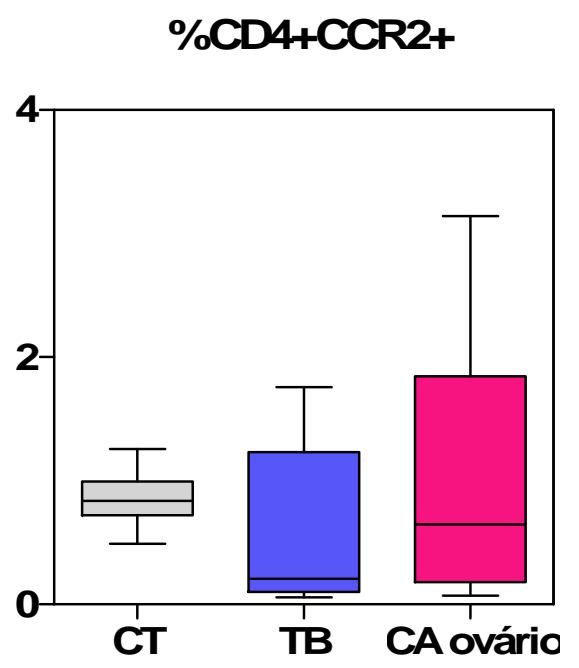

C

$\% C D 4+C C R 5+$

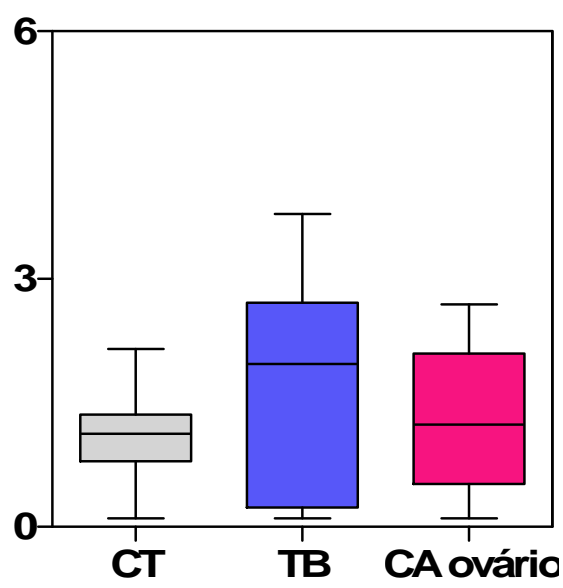

E

\%CD4+CCR3+

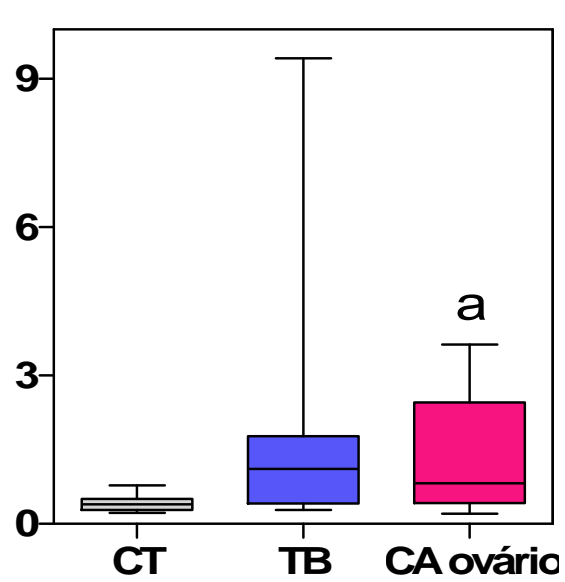

B

$\% C D 4+C X C R 4+$

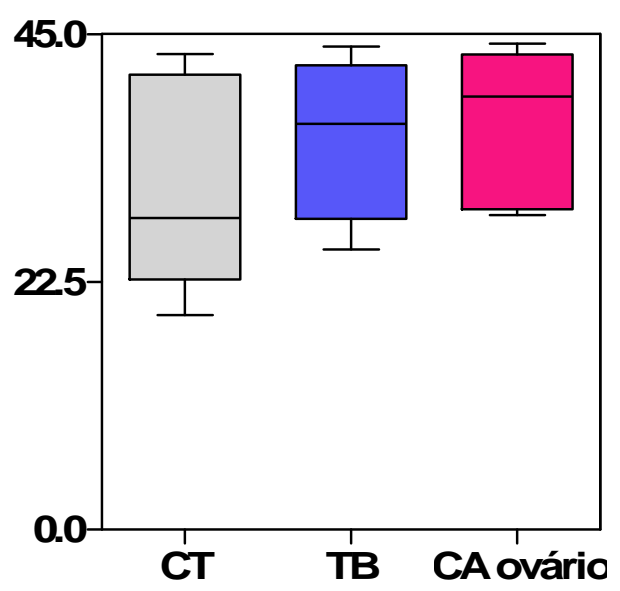

D

\%CD4+CXCR3+

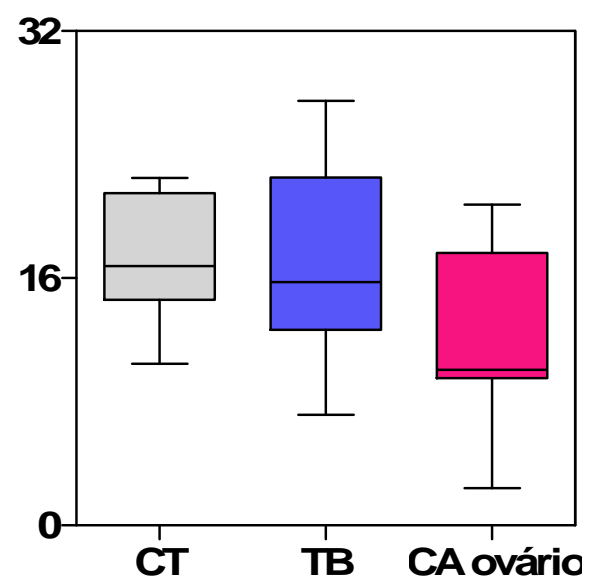

F

\%CD8+CCR2+

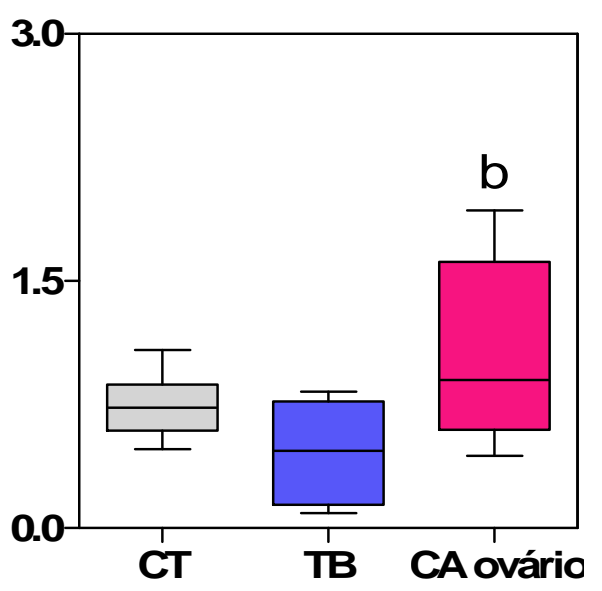


G

$\%$ CD8+CXCR4+

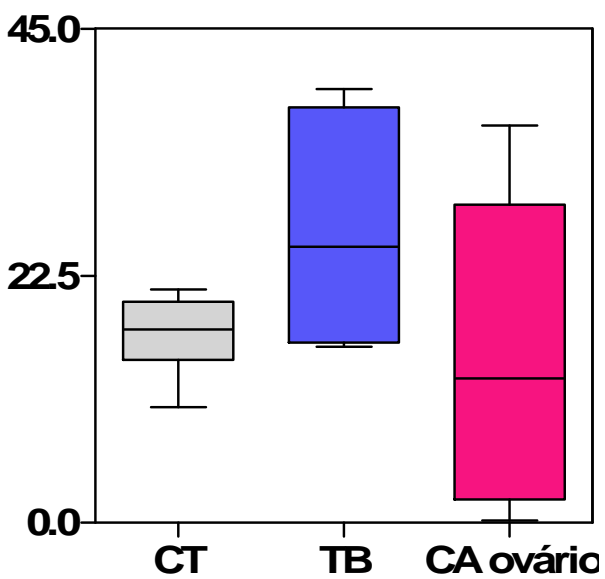

I

$\%$ CD8+CXCR3+

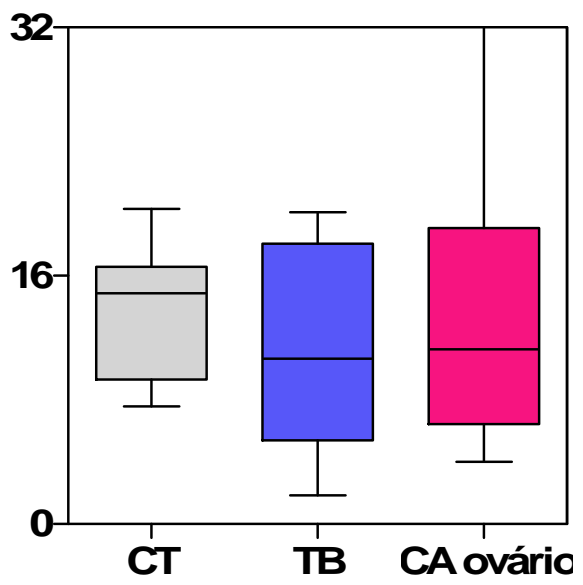

$\mathrm{H}$

$\%$ CD8+CCR5+

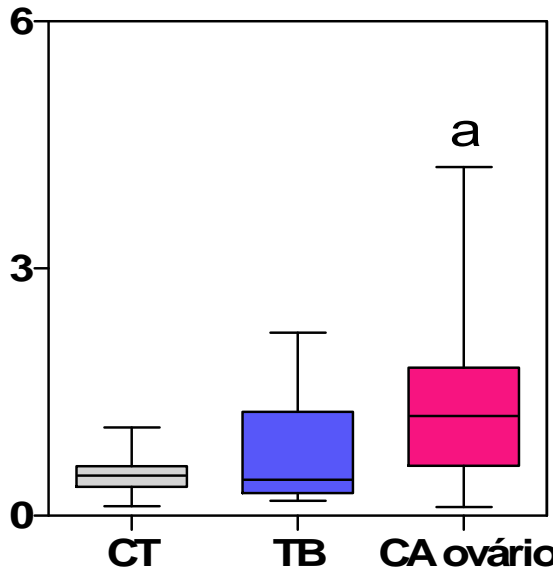

$J$

$\% \mathrm{CD} 8+\mathrm{CCR} 3+$

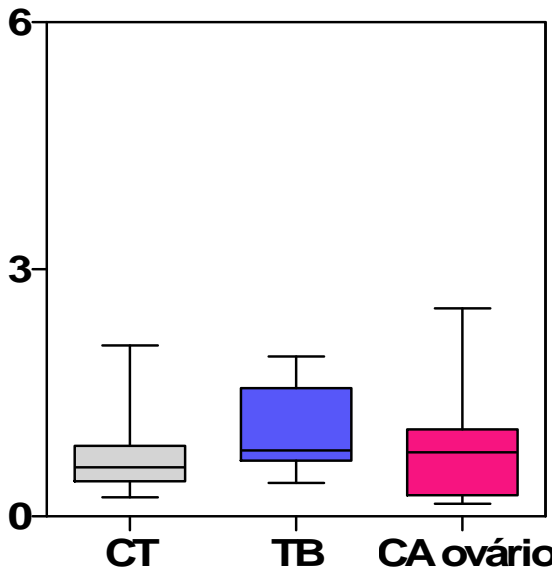

Figura 11: Porcentagem de receptores de quimiocinas CCR2 (A e F), CXCR4 (B e G), CCR5 (C e H), CXCR3 ( $D$ e I) e CCR3 (E e J) por linfócitos T CD4+ e T CD8+, respectivamente, do sangue periférico de mulheres saudáveis $(C T=10)$, mulheres com tumor benigno de ovário $(\mathrm{TB}=09)$ e câncer de ovário $(\mathrm{Ca}$ Ovário $=17)$. Os resultados estão apresentados como porcentagem de linfócitos T CD4+ e T CD8+, expressando os receptores de quimiocinas avaliados, em formato de gráficos de boxes que destacam os valores: mínimo, $25 \%, 50 \%$ mediana, $75 \%$ e máximo. As diferenças entre os grupos foram avaliadas pelo teste de KruskalWallis (3 grupos ) ou Mann-Whitney (2 grupos). As diferenças estatisticamente significativas $(p<0,05)$ entre os grupos CT, TB e Ca Ovário estão representadas pelas letras $a, b$ e c, respectivamente.

( $A$, $p=0,5002)$ - CT vs. TB: $p>0,05$; CT vs. Ca Ovário: $p>0,05$; TB vs. Ca Ovário: $p>0,05$;

(B , $p=0,1773)$ - CT vs. TB: $p>0,05$; CT vs. Ca Ovário: $p>0,05$; TB vs. Ca Ovário: $p>0,05$;

(C , $p=0,7884)$ - CT vs. TB: $p>0,05$; CT vs. Ca Ovário: $p>0,05$; TB vs. Ca Ovário: $p>0,05$; 
( $D, p=0,0590)$ - CT vs. TB: $p>0,05$; CT vs. Ca Ovário: $p>0,05$; TB vs. Ca Ovário: $p>0,05$; ( $E$, $p=0,0233$ ) - CT vs. TB: $p>0,05$; CT vs. Ca Ovário: $p<0,05$; TB vs. Ca Ovário: $p>0,05$; ( $F, p=0,0294)$ - CT vs. TB: $p>0,05$; CT vs. Ca Ovário: $p>0,05$; TB vs. Ca Ovário: $p<0,05$; ( $(p=0,2278$ ) - CT vs. TB: $p>0,05$; CT vs. Ca Ovário: $p>0,05$; TB vs. Ca Ovário: $p>0,05$; $(H, p=0,0216)$ - CT vs. TB: $p>0,05$; CT vs. Ca Ovário: $p<0,05$; TB vs. Ca Ovário: $p>0,05$; (I , $p=0,6692)$ - CT vs. TB: $p>0,05$; CT vs. Ca Ovário: $p>0,05$; TB vs. Ca Ovário: $p>0,05$; (J , $p=0,3309)$ - CT vs. TB: $p>0,05$; CT vs. Ca Ovário: $p>0,05$; TB vs. Ca Ovário: $p>0,05$.

\subsection{Análise ex vivo da porcentagem de linfócitos B ativado (CD19+CD69+), linfócitos B1 (CD19+CD5+) e linfócitos B2 (CD19+CD23+) do sangue periférico de mulheres do grupo controle, neoplasia benigna e maligna.}

As subpopulações de linfócitos B do sangue periférico foram identificadas em ensaios de dupla marcação utilizando-se anticorpos monoclonais anti-CD69 (PE), anti-CD19 (FITC) e anti-CD23 ou anti-CD5 (PE), para identificar as células $\mathrm{B}$ ativadas $\left(\mathrm{CD} 19^{+} \mathrm{CD} 69^{+}\right)$(Figura 12A), as células $\mathrm{B} 1\left(\mathrm{CD} 19^{+} \mathrm{CD} 5^{+}\right)$ (Figura 12B) na população de linfócitos $\mathrm{CD} 19^{+}$e as células $\mathrm{B}$ convencionais $\left(\mathrm{CD} 19^{+} \mathrm{CD} 23^{+}\right)$(Figura 12C) dentro da população de linfócitos totais.

Os resultados do percentual de linfócitos $B$ convencionais $\left(C D 19^{+} C D 23^{+}\right)$na população de linfócitos totais do sangue periférico estão representados na Figura 12C. A análise dos dados revelou uma diminuição significativa $(p<0,05)$ do percentual médio das células $B$ convencionais no grupo de mulheres com tumor benigno quando comparado com o grupo controle.

A Figura 12B mostra os resultados do percentual de linfócitos $B 1\left(C D 19^{+} C D 5^{+}\right)$ na população de linfócitos $B$ do sangue periférico. A análise dos resultados 
revelou diferença significativa entre os grupos $(p=0,0436)$. Já a análise entre os grupos referente os marcadores de linfócitos $B$ convencionais $\left(C D 19^{+} \mathrm{CD}_{23}{ }^{+}\right)$e as células $B$ ativadas $\left(C D 19^{+} C D 69^{+}\right)$não demonstraram diferença significativa.
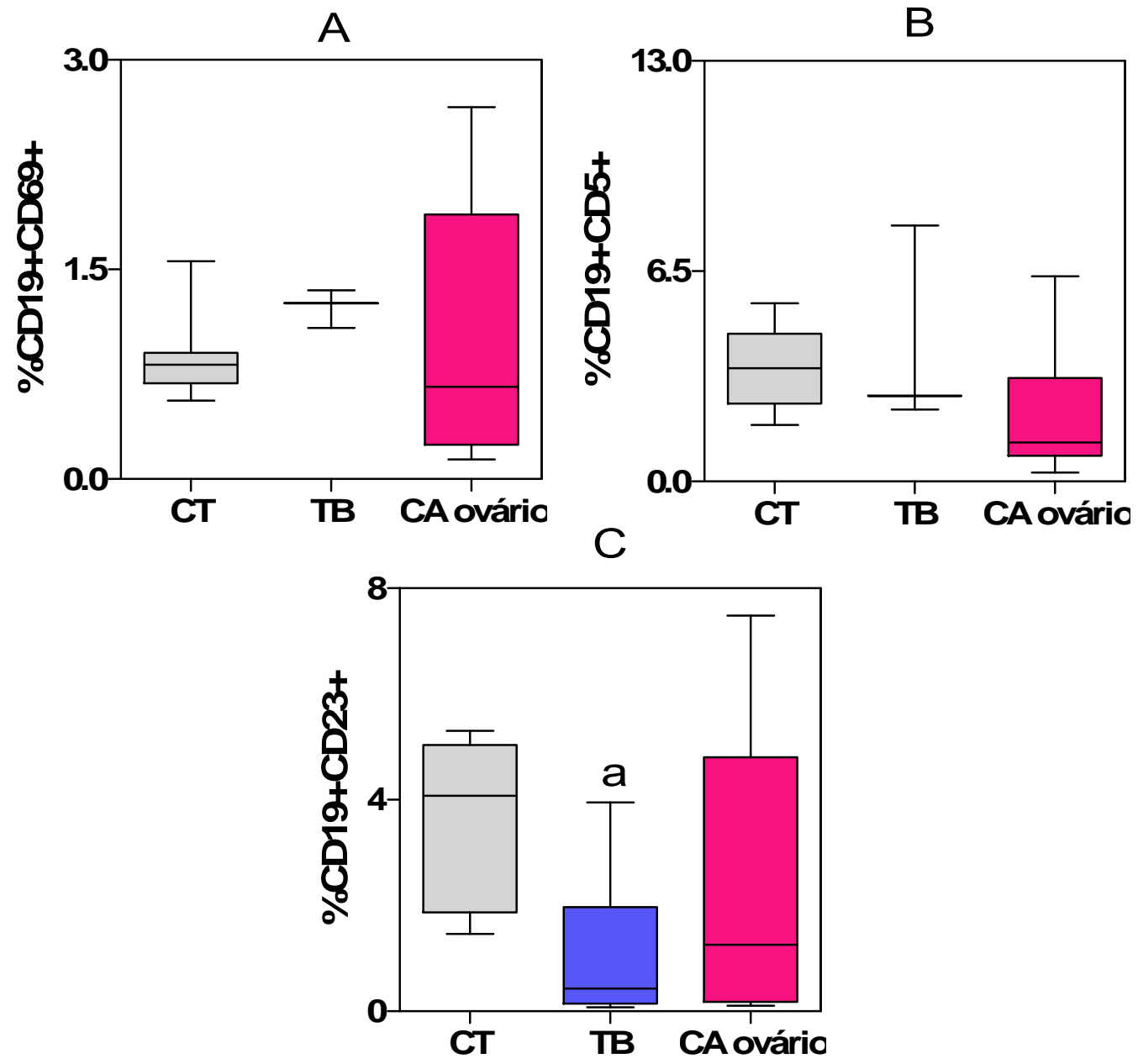

Figura 12: Linfócitos $B$ ativados (CD19+CD69+) (A), linfócitos B1 (CD19+CD5+) (B) e linfócitos $B 2(C D 19+C D 23+)(C)$ do sangue periférico de mulheres saudáveis $(C T=10)$, mulheres com tumor benigno $(T B=09)$ e câncer de ovário $(C A$ Ovário $=17)$. Os resultados estão apresentados como porcentagem dos linfócitos B ativados, linfócitos B1 e B2 expressando o marcador de superfície avaliado, em formato de gráfico de boxe que destaca os valores: mínimo, $25 \%, 50 \%$-mediana, $75 \%$ e máximo. As diferenças entre os grupos foram avaliadas pelo teste de Kruskal-Wallis ( 3 grupos ) ou Mann-Whitney (2 grupos). A diferença estatisticamente significativa $(p<0,05)$ entre o grupos CT e TB está representada pela letras a. (A , $p=0,3279)$ - CT vs. TB: $p>0,05$; CT vs. Ca Ovário: $p>0,05$; TB vs. Ca Ovário: $p>0,05$; (B , $p=0,0436)$ - CT vs. TB: $p>0,05$; CT vs. Ca Ovário: $p>0,05$; TB vs. Ca Ovário: $p>0,05$; (C , $p=0,0546$ ) - CT vs. TB: $p<0,05$; CT vs. Ca Ovário: $p>0,05$; TB vs. Ca Ovário: $p>0,05$. 


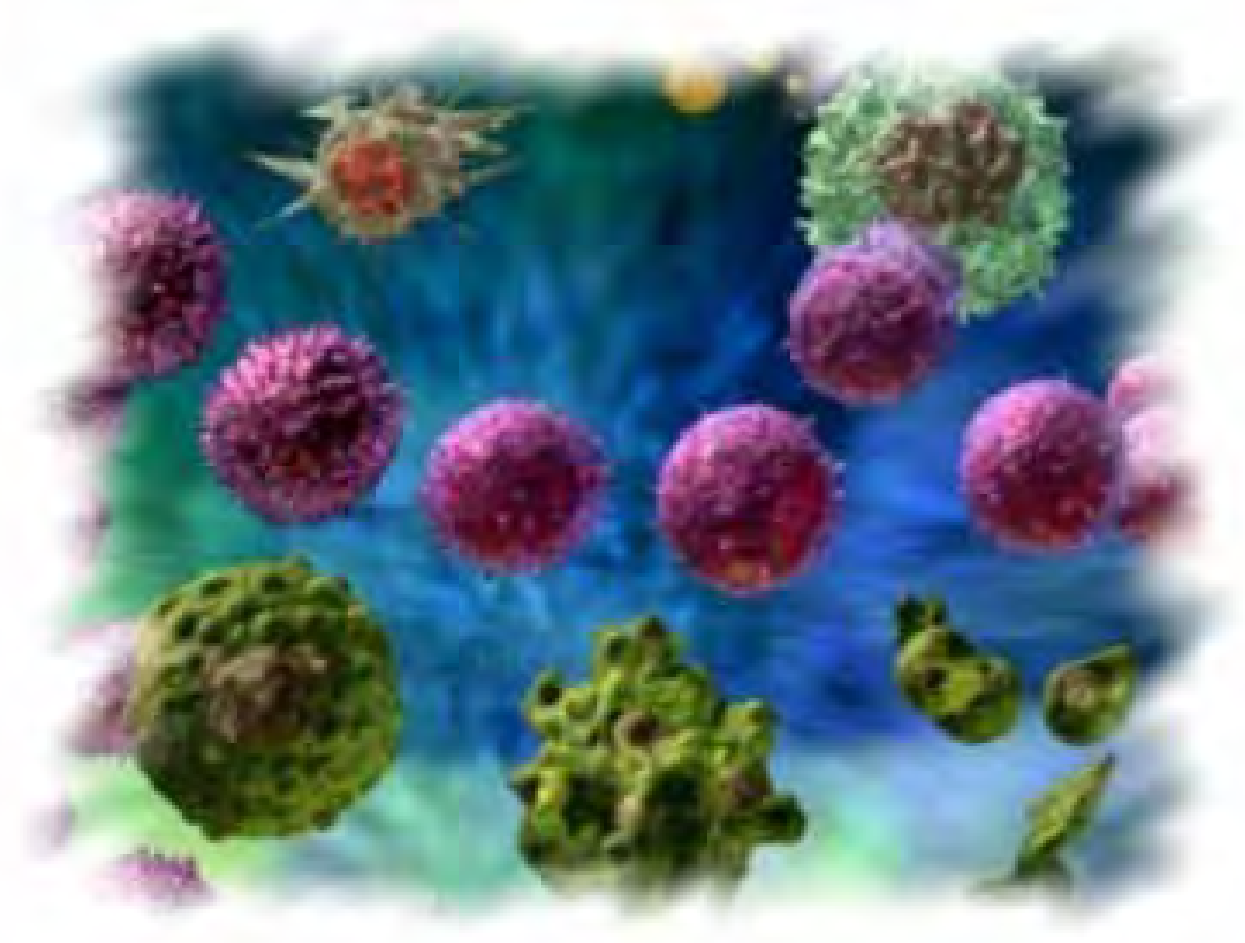

5. Discussãa 
O CEO constitui patologia de grande importância dentre os tumores ginecológicos devido ao seu caráter insidioso e sua alta letalidade [1]. A detecção precoce poderia, teoricamente, melhorar a sobrevida. Entretanto, isso continua a ser um problema devido à raridade da doença na população em geral, à falta de biomarcadores sensíveis e específicos e à rápida progressão desse câncer, assintomático em estadios iniciais [28]. Isso mostra a importância do aprimoramento dos conhecimentos da biologia molecular, fisiopatologia e imunologia relacionados ao CEO.

O papel do microambiente tumoral no reconhecimento e progressão do câncer tem sido cada vez mais estudado, e as interações entre as células imunes, as células tumorais e os componentes moleculares do tumor exercem influência significativa na progressão da doença [37].

Vários estudos [28, 38-45] têm demonstrado a presença da resposta imune tumoral no momento do diagnóstico. Entretanto, ainda não há consenso sobre o real valor do infiltrado leucocitário no microambiente tumoral.

As células T e os anticorpos contra antígenos específicos do tumor podem ser detectados no sangue periférico e no sítio tumoral, entretanto, as células neoplásicas conseguem escapar à essa imunovigilância através de diversos mencanismos.

Alterações de função e sobrevida dos linfócitos $T$ e B têm sido descritas. Experimentos demonstram supressão dos linfócitos $T$ e $B$ pelas células $T$ regulatórias, pelas células supressoras mielóides, e pela ação de citocinas sintetizadas no microambiente tumoral. Observa-se também aumento da taxa 
de apoptose desses linfócitos no organismo do hospedeiro, além da alteração de sinalização para recrutamento e ativação celular [28, 38, 39, 46, 47].

Certos experimentos demonstram a hiporregulação de moléculas da superfície celular que servem de reconhecimento para as células imunes. Desse modo, ocorre alteração na expressão das moléculas de superfície HLA e alterações nos componentes de processamento antigênico [28, 38, 47-49].

É importante considerar que a resposta imune representa um somatório de interações entre moléculas sinalizadoras sob a forma de fatores solúveis, receptores de superfície celular, imunoglobulinas e citocinas. Assim o direcionamento da resposta do hospedeiro com CEO não deve ser avaliado de forma restrita aos aspectos imunofenotípicos da membrana celular, devendo ser ampliado para uma discussão mais funcional envolvendo outros aspectos da resposta imune.

Este estudo avaliou os seguintes marcadores de superfície celular: CD4, CD8, HLA-DR, CD54, CD62L, CD18, CCR2, CXCR4, CCR5, CCR3, CXCR3, CD25, CD5, CD69, CD19 e CD23, expressos pelos linfócitos que são importantes para a resposta imune adaptativa do hospedeiro. O conhecimento da fisiopatologia da resposta imune antitumoral é de grande importância para aprimoramento do diagnóstico e desenvolvimento de terapias antitumorais mais efetivas.

Para a identificação das moléculas de superfície celular expressas pelas células imunes. foi realizado o método de imunofenotipagem pela citometria de 
fluxo. O uso da citometria de fluxo permite a análise quantitativa de múltiplos parâmetros em uma única amostra; utilização de mínimos volumes de amostra para obter seus resultados; reprodutibilidade comparáveis com outras técnicas, comparação direta com os ensaios já existentes e ainda avaliação mais rápida de múltiplas amostra em uma mesma plataforma [50-52]

Com o desenvolvimento da técnica, automatização de seus processos e a possibilidade de livre associação entre os parâmetros para estudo, a citometria de fluxo ganha ainda mais em agilidade, ampliando sua possibilidade de inserção na abordagem clínica diária. Painéis de marcadores bioquímicos poderiam ser avaliados conjuntamente e seus achados utilizados como biomarcadores complexos para detecção de tumores iniciais, ou melhor avaliação prognóstica de cada caso.

Foi observado que as pacientes com tumor maligno de ovário possuem menor percentual de células T circulantes quando comparados com o grupo benigno e controle. Estudos relatam que a taxa de sobrevida livre de doença é maior, no grupo de mulheres com câncer de ovário que apresentam maior infiltrado tumoral de células $\mathrm{T}$ quando comparado com o grupo com menor percentual [28, 38, 39]. Este dado é interessante, uma vez que observa-se, sistemicamente, um menor percentual de células T no grupo de pacientes com CEO, quando comparadas com o controle. Essa redução de linfócitos pode ser um indicador de alteração da resposta imune do hospedeiro ao tumor [53-55]. Esses achados dão suporte à hipótese de serem estes linfócitos de grande importância no controle da progressão da doença. 
Não se conhece o real significado da presença linfócitos B e seus anticorpos no microambiente tumoral de pacientes com CEO. Alguns trabalhos mostram que há evidências de produção de anticorpos monoclonais específicos contra o tumor, porém a ação efetiva desses anticorpos contra os antígenos tumorais ainda é incerta $[26,56]$. Neste estudo não foi observado diferenças significativas na porcentagem de linfócitos B entre os grupos.

Alguns trabalhos verificaram o aumento da ativação de linfócitos $T$ em pacientes com CEO, porém essas células apresentaram-se disfuncionais, com alteração de sinalização e aumento de indução para apoptose $[27,39,49,57]$. Entretanto, no presente estudo, não observou-se diferenças significativas no percentual de moléculas de ativação celular (HLA-DR) nos linfócitos CD4+ e $\mathrm{CD}^{+}$

Em relação à análise das moléculas de adesão celular avaliadas (CD54, CD62L, CD18), verificou-se redução significativa do número de linfócitos TCD4+CD62L+ e TCD8+CD62L+ nas mulheres com câncer quando comparadas com as com tumor benigno e controle, respectivamente. A diminuição das moléculas de adesão nas células imunes de pacientes com câncer já foi demonstrada por diversos trabalhos. Essa alteração fenotípica pode auxiliar no crescimento e desenvolvimento tumoral $[27,58]$.

Segundo alguns autores, a presença de linfócitos T CD25+ ativados está 
associada à progressão tumoral, especialmente por se ligar à IL-2, aumentando a resposta inflamatória crônica nessas pacientes $[38,58]$. Em nossas análises não foi observado diferenças significativas no número de linfócitos T CD4+ CD25+ e linfócitos T CD4+ CD25+ ${ }^{\mathrm{HIGH}}$

Os receptores de quimiocinas possuem funções importantes que coordenam a diferenciação e o tráfego de leucócitos. Sendo assim, neste estudo foi realizada a análise do número de receptores de quimiocinas em linfócitos circulantes de mulheres do grupo controle, mulheres com tumor benigno e com câncer de ovário.

Vários estudos já demonstraram a ação das citocinas e quimiocinas favorecendo o crescimento neoplásico e a metastatização, por aumento da proliferação celular, estimulando a mobilidade e migração celular ou potencializando a angiogênese no tecido tumoral [59, 60]. Entretanto, nas neoplasias, a expressão destas quimiocinas e citocinas ainda é controversa. Os tumores podem criar mecanismos para impedir ou modular a ação do sistema imune. Estas ações podem apresentar características individualizadas de neoplasia para neoplasia [61]. Em modelo animal foi demonstrado que as quimiocinas se associam com a angiogênese e com o crescimento tumoral. Por outro lado, algumas podem iniciar ou incrementar a resposta imunológica do hospedeiro contra a implantação tumoral ou ainda inibir a neovascularização. A análise dos resultados deste estudo demonstrou aumento significativo do 
número de linfócitos T CD4+ CCR3+, TCD8+CCR2+ e TCD8+CCR5+ no grupo do câncer de ovário quando comparado com os outros grupos.

Em relação à análise dos linfócitos B1 (CD19+CD5+), verificou-se uma diferença significativa entre os três grupos, observando-se uma diminuição do percentual de células dos grupos TB e CA Ovário quando comparados com o grupo CT. Além disso, foi possível observar uma redução do percentual de células B2 (CD19+ CD23+) do grupo TB quando comparado ao grupo controle. Os linfócitos B1 e B2 são importantes componentes da resposta imune. Em relação às diferentes atividades funcionais, as células B2 são mediadoras da resposta imune adaptativa, respondendo a antígenos protéicos convencionais, com o auxílio das células T. Já células B1 são consideradas efetoras da resposta imune inata, respondendo a antígenos independentemente das células T [62]. Estas alterações, relacionadas a diminuição das células B1 e B2 podem estar associados com o favorecimento da progressão tumoral [63].

A dinâmica entre tumor e sistema imune mostra-se com grande espectro de variáveis. O conhecimento sobre o perfil de apresentação dos agentes deste sistema imune nas neoplasias é de grande importância para o melhor entendimento de todo o sistema imune e a resposta do organismo aos tumores.

A utilização de anticorpos monoclonais e a imunofenotipagem, por meio de citometria de fluxo, permitiu mostrar a existência de alterações imunológicas no microambiente tumoral. Estudos posteriores, mediante técnicas avançadas de biologia celular e molecular, com maior número de pacientes, avaliando outros 
marcadores da resposta imune e outras vias desta resposta, deverão fornecer melhor entendimento dos mecanismos envolvidos que ocorrem no câncer epitelial de ovário. A compreensão desses mecanismos permitirá vislumbrar novas perspectivas terapêuticas para esta doença e diagnóstico precoce através de biomarcadores. 


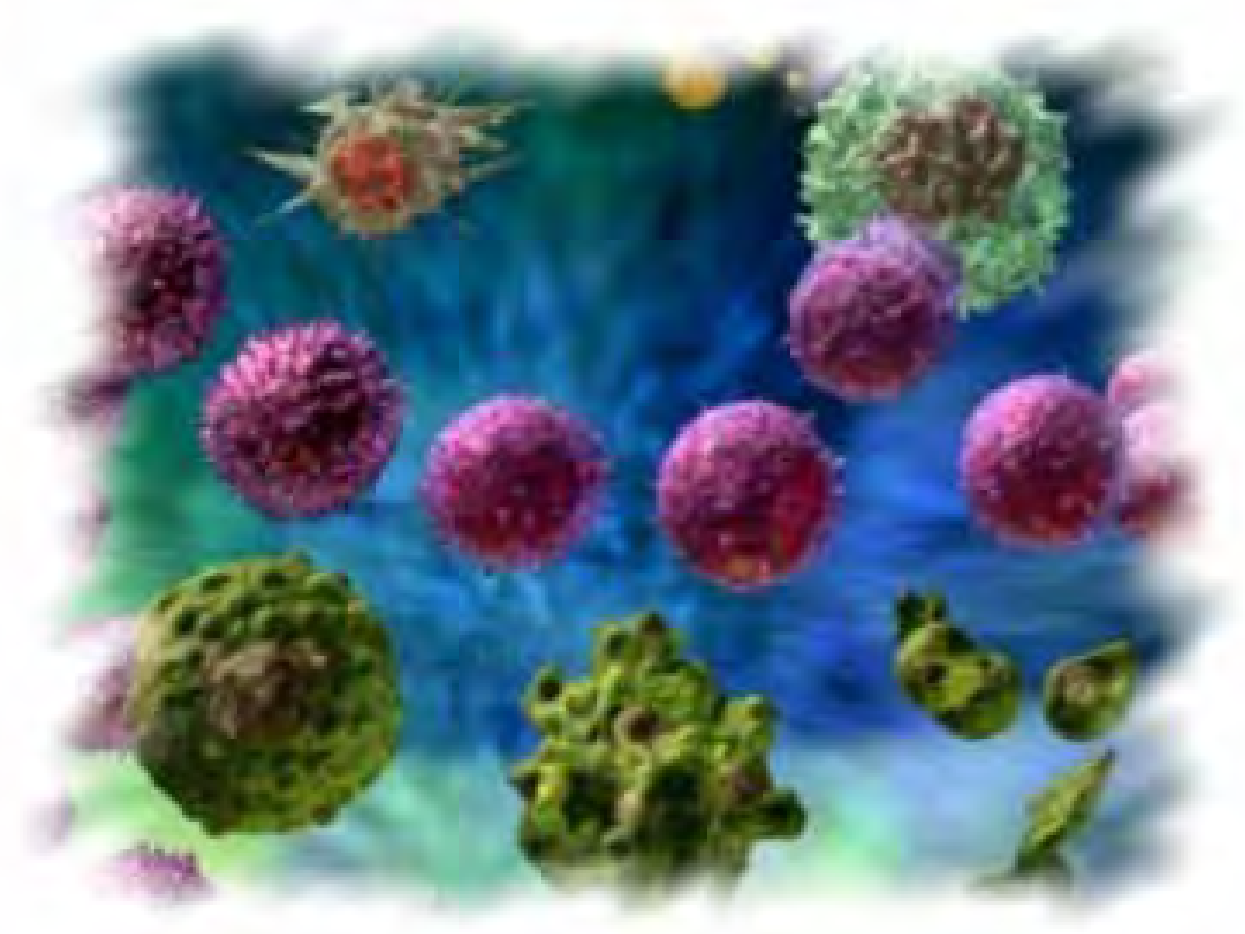

6. Canclusãa 
O estudo da resposta imune humoral pelas células $T$ e linfócitos $B$, associados aos marcadores CD4, CD8, HLA-DR, CD54, CD62L, CD18, CCR2, CXCR4, CCR5, CCR3, CXCR3, CD25, CD5, CD69, CD19, CD23; permite concluir que:

- A população de linfócitos T CD8+ apresentou um maior número de alterações dos marcadores de superfície celular quando comparado com o grupo controle, o que pode estar associado com o estabelecimento e manutenção de um microambiente favorável à progressão tumoral.

- $\quad$ As alterações observadas com a diminuição do percentual das células B1 e B2 no sangue periférico das mulheres com neoplasia quando comparado com o grupo controle, podem estar associados com o favorecimento da progressão tumoral. 


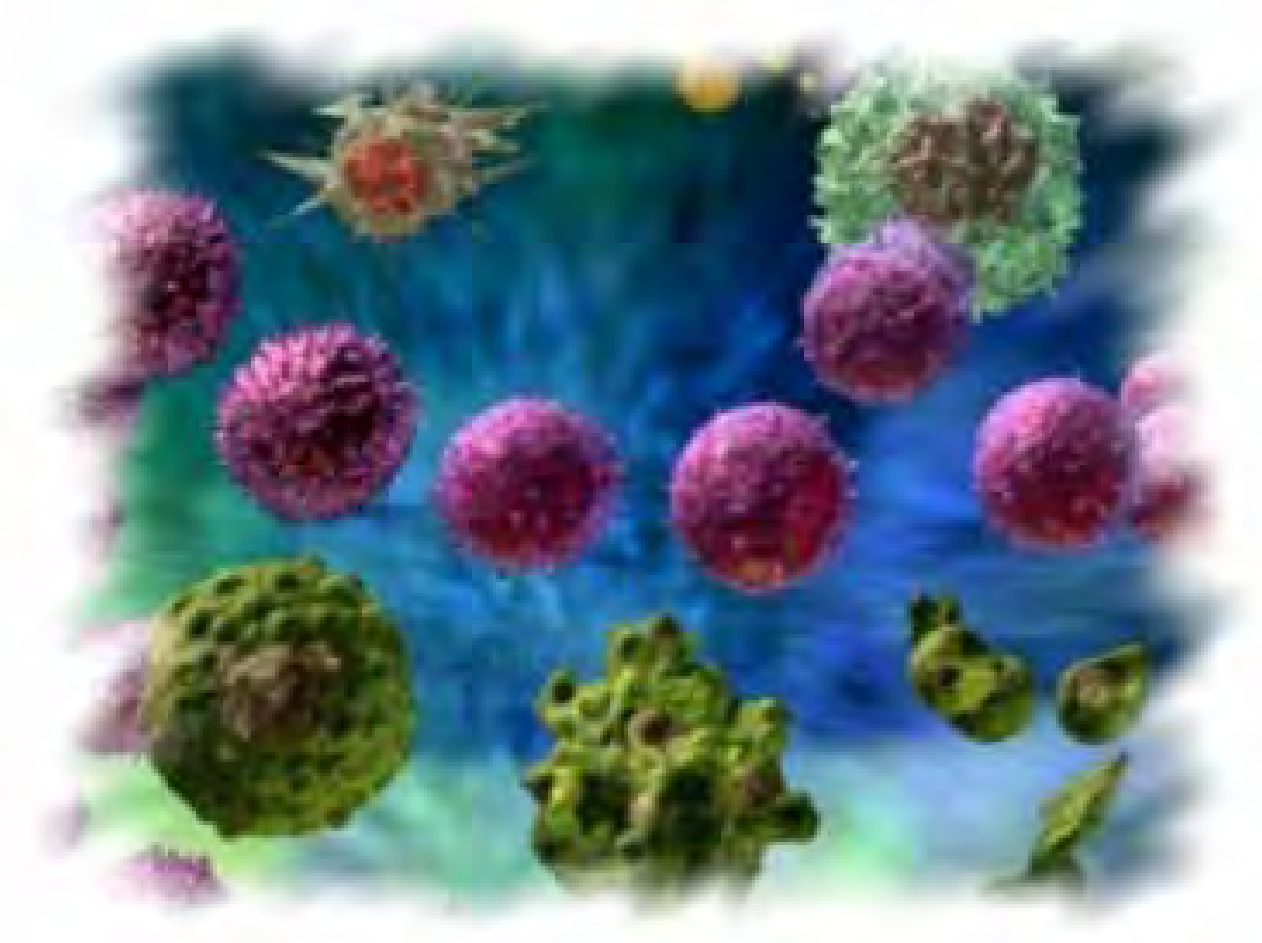

7. Referencias Bililiagráficas 
1. Silva-Filho, A.L., et al., Cirurgia não Ginecológica em Pacientes com Câncer de Ovário. RBGO, 2004. 26(5): p. 411-416.

2. Jemal, A., et al., Cancer statistics, 2005. CA Cancer J Clin, 2005. 55(1): p. $10-30$.

3. SOCIETY, A.C., Cancer Facts \& Figures 2009. American Cancer Society, 2009: p. 1-70.

4. Look, K., Epidemiology, etiology, and screening of ovarian cancer, in Ovarian cancer S.C. Rubin and G.P. Sutton, Editors. 2001, Lippincott Williams \& Wilkins: Philadelphia. p. 167-180.

5. Reis, F.M., et al., Biochemical markers of ovarian cancer: diagnostic and prognostic value. Italian Journal Of Gynaecology And Obstetrics, 2004. 16(3): p. 94-99.

6. Brewer, M.A., et al., Prevention of ovarian cancer: intraepithelial neoplasia. Clin Cancer Res, 2003. 9(1): p. 20-30.

7. Roett, M.A. and P. Evans, Ovarian cancer: an overview. Am Fam Physician, 2009. 80(6): p. 609-16.

8. Ries, L.A., et al., The annual report to the nation on the status of cancer, 1973-1997, with a special section on colorectal cancer. Cancer, 2000. 88(10): p. 2398-424.

9. Medzhitov, R. and C.A. Janeway, Jr., How does the immune system distinguish self from nonself? Semin Immunol, 2000. 12(3): p. 185-8; discussion 257-344.

10. Moser, M. and K.M. Murphy, Dendritic cell regulation of TH1-TH2 development. Nat Immunol, 2000. 1(3): p. 199-205.

11. Constant, S.L. and K. Bottomly, Induction of Th1 and Th2 CD4+ T cell responses: the alternative approaches. Annu Rev Immunol, 1997. 15: p. 297-322.

12. Andres, P.G., et al., Mice with a selective deletion of the CC chemokine receptors 5 or 2 are protected from dextran sodium sulfate-mediated colitis: lack of CC chemokine receptor 5 expression results in a NK1.1+ lymphocyte-associated Th2-type immune response in the intestine. J Immunol, 2000. 164(12): p. 6303-12.

13. Svanborg, C., G. Godaly, and M. Hedlund, Cytokine responses during mucosal infections: role in disease pathogenesis and host defence. Curr Opin Microbiol, 1999. 2(1): p. 99-105. 
14. Reid, R.R., et al., The role of complement receptors CD21/CD35 in positive selection of B-1 cells. Curr Top Microbiol Immunol, 2000. 252: p. 57-65.

15. Bos, N.A., J.J. Cebra, and F.G. Kroese, B-1 cells and the intestinal microflora. Curr Top Microbiol Immunol, 2000. 252: p. 211-20.

16. Berland, R. and H.H. Wortis, Origins and functions of B-1 cells with notes on the role of CD5. Annu Rev Immunol, 2002. 20: p. 253-300.

17. Bouvier, M., Accessory proteins and the assembly of human class I MHC molecules: a molecular and structural perspective. Mol Immunol, 2003. 39(12): p. 697-706.

18. Sezerman, U., S. Vajda, and C. DeLisi, Free energy mapping of class I MHC molecules and structural determination of bound peptides. Protein Sci, 1996. 5(7): p. 1272-81.

19. Mieno, M., et al., CD4-CD8- T cell receptor alpha beta T cells: generation of an in vitro major histocompatibility complex class I specific cytotoxic $T$ lymphocyte response and allogeneic tumor rejection. J Exp Med, 1991. 174(1): p. 193-201.

20. Voelkl, S., et al., Characterization of MHC class-I restricted TCRalphabeta+ CD4- CD8- double negative $T$ cells recognizing the gp100 antigen from a melanoma patient after gp100 vaccination. Cancer Immunol Immunother, 2009. 58(5): p. 709-18.

21. Fremont, D.H., et al., Structures of an MHC class II molecule with covalently bound single peptides. Science, 1996. 272(5264): p. 1001-4.

22. Brocke, P., et al., HLA-DM, HLA-DO and tapasin: functional similarities and differences. Curr Opin Immunol, 2002. 14(1): p. 22-9.

23. Villadangos, J.A., Presentation of antigens by MHC class II molecules: getting the most out of them. Mol Immunol, 2001. 38(5): p. 329-46.

24. Williams, A., C.A. Peh, and T. Elliott, The cell biology of MHC class I antigen presentation. Tissue Antigens, 2002. 59(1): p. 3-17.

25. Dranoff, G., Cytokines in cancer pathogenesis and cancer therapy. Nat Rev Cancer, 2004. 4(1): p. 11-22.

26. Dunn, G.P., L.J. Old, and R.D. Schreiber, The immunobiology of cancer immunosurveillance and immunoediting. Immunity, 2004. 21(2): p. 13748. 
27. Whiteside, T.L., Immune responses to malignancies. J Allergy Clin Immunol, 2003. 111(2 Suppl): p. S677-86.

28. Zhang, L., et al., Intratumoral $T$ cells, recurrence, and survival in epithelial ovarian cancer. N Engl J Med, 2003. 348(3): p. 203-13.

29. Pages, F., et al., Effector memory $T$ cells, early metastasis, and survival in colorectal cancer. N Engl J Med, 2005. 353(25): p. 2654-66.

30. Clark, W.H., Jr., et al., Model predicting survival in stage I melanoma based on tumor progression. J Natl Cancer Inst, 1989. 81(24): p. 1893904.

31. Matzinger, P., The danger model: a renewed sense of self. Science, 2002. 296(5566): p. 301-5.

32. Gabrilovich, D., Mechanisms and functional significance of tumourinduced dendritic-cell defects. Nat Rev Immunol, 2004. 4(12): p. 941-52.

33. Zisman, A., A.J. Pantuck, and A. Belldegrun, Immune and genetic therapies for advanced renal cell carcinoma. Rev Urol, 2000. 2(1): p. 5460.

34. Moretta, A., et al., What is a natural killer cell? Nat Immunol, 2002. 3(1): p. 6-8.

35. Dunn, G.P., L.J. Old, and R.D. Schreiber, The three Es of cancer immunoediting. Annu Rev Immunol, 2004. 22: p. 329-60.

36. Hollenbeak, C.S., et al., Increased incidence of melanoma in renal transplantation recipients. Cancer, 2005. 104(9): p. 1962-7.

37. Rosenberg, S.A., J.C. Yang, and N.P. Restifo, Cancer immunotherapy: moving beyond current vaccines. Nat Med, 2004. 10(9): p. 909-15.

38. Shah, C.A., et al., Intratumoral T cells, tumor-associated macrophages, and regulatory $T$ cells: association with p53 mutations, circulating tumor DNA and survival in women with ovarian cancer. Gynecol Oncol, 2008. 109(2): p. 215-9.

39. Tomsova, M., et al., Prognostic significance of CD3+ tumor-infiltrating lymphocytes in ovarian carcinoma. Gynecol Oncol, 2008. 108(2): p. 41520.

40. Leffers, N., et al., Prognostic significance of tumor-infiltrating $T$ lymphocytes in primary and metastatic lesions of advanced stage ovarian cancer. Cancer Immunol Immunother, 2009. 58(3): p. 449-59. 
41. Wang, X., et al., Monocyte/macrophage and T-cell infiltrates in peritoneum of patients with ovarian cancer or benign pelvic disease. $\mathrm{J}$ Transl Med, 2006. 4: p. 30.

42. Ness, R.B. and C. Cottreau, Possible role of ovarian epithelial inflammation in ovarian cancer. J Natl Cancer Inst, 1999. 91(17): p. 1459-67.

43. Dietl, J., J.B. Engel, and J. Wischhusen, The role of regulatory $T$ cells in ovarian cancer. Int J Gynecol Cancer, 2007. 17(4): p. 764-70.

44. Hung, C.F., et al., Antigen-specific immunotherapy of cervical and ovarian cancer. Immunol Rev, 2008. 222: p. 43-69.

45. Andrade, S.P., et al., Sponge-induced angiogenesis in mice and the pharmacological reactivity of the neovasculature quantitated by a fluorimetric method. Microvasc Res, 1997. 54(3): p. 253-61.

46. Sakaguchi, S., et al., Immunologic tolerance maintained by CD25+ CD4+ regulatory $T$ cells: their common role in controlling autoimmunity, tumor immunity, and transplantation tolerance. Immunol Rev, 2001. 182: p. 1832.

47. Adams, S.F., et al., Intraepithelial T cells and tumor proliferation: impact on the benefit from surgical cytoreduction in advanced serous ovarian cancer. Cancer, 2009. 115(13): p. 2891-902.

48. Hamerman, J.A., K. Ogasawara, and L.L. Lanier, NK cells in innate immunity. Curr Opin Immunol, 2005. 17(1): p. 29-35.

49. Nelson, B.H., The impact of T-cell immunity on ovarian cancer outcomes. Immunol Rev, 2008. 222: p. 101-16.

50. Morgan, E., et al., Cytometric bead array: a multiplexed assay platform with applications in various areas of biology. Clin Immunol, 2004. 110(3): p. 252-66.

51. Pierangeli, S.S., L.K. Silva, and E.N. Harris, $A$ flow cytometric assay for the detection of antiphospholipid antibodies. Am Clin Lab, 1999. 18(6): p. 18-9.

52. Lund-Johansen, F., et al., Flow cytometric analysis of immunoprecipitates: high-throughput analysis of protein phosphorylation and protein-protein interactions. Cytometry, 2000. 39(4): p. 250-9.

53. Sato, E., et al., Intraepithelial CD8+ tumor-infiltrating lymphocytes and a high $C D 8+/$ regulatory $T$ cell ratio are associated with favorable prognosis in ovarian cancer. Proc Natl Acad Sci U S A, 2005. 102(51): p. 18538-43. 
54. Naito, Y., et al., CD8+ $T$ cells infiltrated within cancer cell nests as a prognostic factor in human colorectal cancer. Cancer Res, 1998. 58(16): p. 3491-4.

55. Nakano, O., et al., Proliferative activity of intratumoral CD8(+) Tlymphocytes as a prognostic factor in human renal cell carcinoma: clinicopathologic demonstration of antitumor immunity. Cancer Res, 2001. 61(13): p. 5132-6.

56. Bellati, F., et al., Immunology of gynecologic neoplasms: analysis of the prognostic significance of the immune status. Curr Cancer Drug Targets, 2009. 9(4): p. 541-65.

57. Bukowski, R.M., et al., Signal transduction abnormalities in $T$ lymphocytes from patients with advanced renal carcinoma: clinical relevance and effects of cytokine therapy. Clin Cancer Res, 1998. 4(10): p. 2337-47.

58. Zou, W., Regulatory $T$ cells, tumour immunity and immunotherapy. Nat Rev Immunol, 2006. 6(4): p. 295-307.

59. Balkwill, F., Cancer and the chemokine network. Nat Rev Cancer, 2004. 4(7): p. 540-50.

60. Wang, J.M., et al., Chemokines and their role in tumor growth and metastasis. J Immunol Methods, 1998. 220(1-2): p. 1-17.

61. Wong, M.M. and E.N. Fish, Chemokines: attractive mediators of the immune response. Semin Immunol, 2003. 15(1): p. 5-14.

62. Veneri, D., et al., Peripheral blood CD5-positive $B$ lymphocytes (B-1a cells) after allogeneic stem cell transplantation for acute myeloid leukaemia in humans. Blood Transfus, 2008. 6(4): p. 220-4.

63. Catelan, T.T.T., et al., Linfócitos B: da imunobiologia aos imunobiológicos.

Sinopse de Reumatologia, 2008: p. 35-57. 


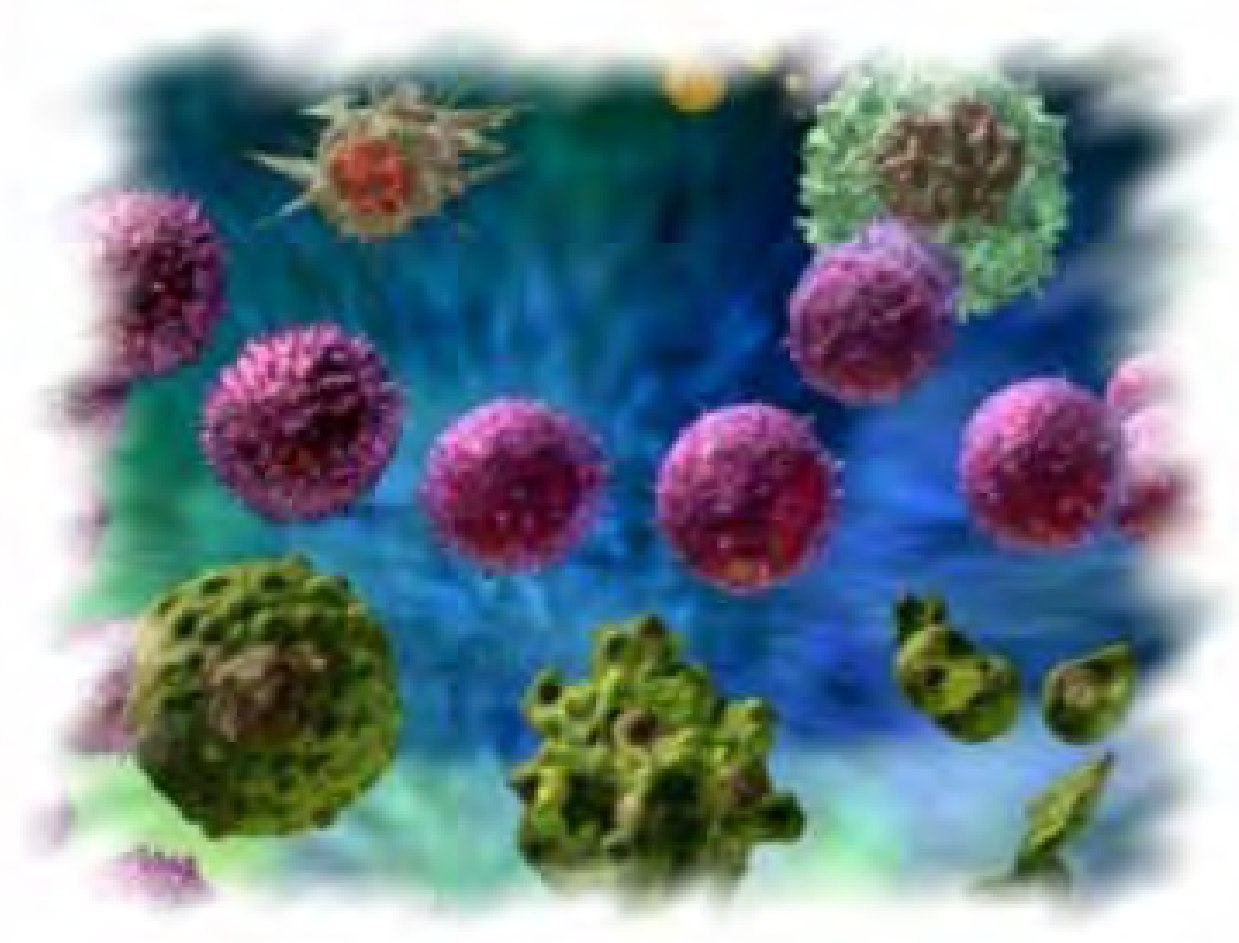

8. Anexas 


\title{
I. Parecer do Comitê de Ética em Pesquisa da Universidade Federal de Minas Gerais
}

\section{UNIVTRSIDADE TEDERAI. DE MINAS GERAIS}

COMITÉ DE ETICA EM PESQUISA - COEP

Parecer $n^{\circ}$. ETIC $326 / 08$

\begin{abstract}
Interessado(a): Prof. Agnaldo Lopes Silva Filho
Departamento de Ginecologia e Obstetrícia

Faculdade de Medicina - UFMG
\end{abstract}

\section{DECISĀO}

O Comitè de Ética em Pesquisa da UFMG - COEP aprovou, no dia 17 de setembro de 2008, após atendidas as solicitaçōes de diligência, o projeto de pesquișa intitulado "Avaliação da resposta imune em pacientes com câncer ginecológico" bem como o Termo de Consentimento Livre e Esclarecido.

O relatório final ou parcial deverá ser encaminhado ao COEP um ano após o início do projeto.

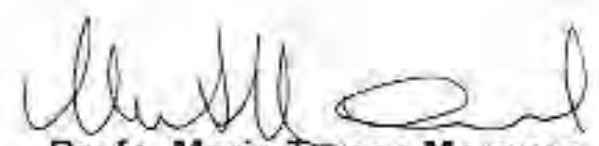

Profa. Maria Teresa Marques Amaral Coordenadora do COEP-UFMG 


\section{Consentimento Livre e Esclarecido}

\section{TERMO DE CONSENTI MENTO LI VRE E ESCLARECIDO AVALI AÇÃO DA RESPOSTA I MUNE EM PACI ENTES COM CÂNCER GI NECOLÓGI CO}

A senhora está sendo convidada a participar de um projeto de pesquisa que visa investigar a presença de algumas substâncias no sangue, ascite (líquido localizado no abdome) e no útero ou ovário que possam nos ajudar a fazer o diagnóstico precoce das doenças desse órgão.

A participação no estudo consiste em doar uma amostra de sangue, ascite e um fragmento da peça cirúrgica (útero ou ovário) para serem analisados. Essa participação não modifica o tratamento proposto para a sua doença.

A sua identidade será preservada e o seu direito de não participar no estudo não a prejudicará no seu tratamento.

1. DESCRICCÃO DAS COMPLICAÇÕES DOS MÉTODOS: não haverá aumento do risco de complicações devido à retirada de uma biópsia do útero ou ovário. A coleta de sangue será realizada no momento da punção para administração do soro. As complicações serão as mesmas relacionadas ao procedimento cirúrgico (retirada do útero e/ou ovário).

2. DESCRICCÃO DA ANESTESIA: poderá haver necessidade de me submeter à anestesia para a realização da cirurgia proposta. O tipo de anestesia vai depender do procedimento realizado, podendo ser bloqueio (anestesia peridural ou raque) ou geral.

3. DESTINO DA PEÇA OPERATÓRIA: a peça cirúrgica será encaminhada à Anatomia Patológica para ser examinada.

4. Recebi todas as informações que desejava conhecer e a possibilidade de fazer perguntas e questionar dúvidas.

5. Também entendi que, a qualquer momento e sem necessidade de dar nenhuma explicação poderei suspender o consentimento que agora presto.

\section{Investigador: Prof. Agnaldo L. Silva Filho}

Endereço: Avenida Professor Alfredo Balena 110/40andar. Santa Efigênia. Belo Horizonte. Minas Gerais. CEP: 30130 100. Tel: (31) 32489764 / 92250909

Dra. Andréa Teixeira de Carvalho: Tel (31) 33497764

\section{COEP/ UFMG:}

Endereço: Av. Pres. Antônio Carlos, 6627 - Unid. Adm. II - 2o andar - SI 2005 Pampulha - Belo Horizonte/MG - 31.270-090 Tel: (31) 34094592

Nome:

Registro:

Endereço:

Telefone:

Carteira de identidade:

De pleno acordo

Cidade:

Data:

Assinatura do médico

Assinatura da paciente

Testemunha

Testemunha 


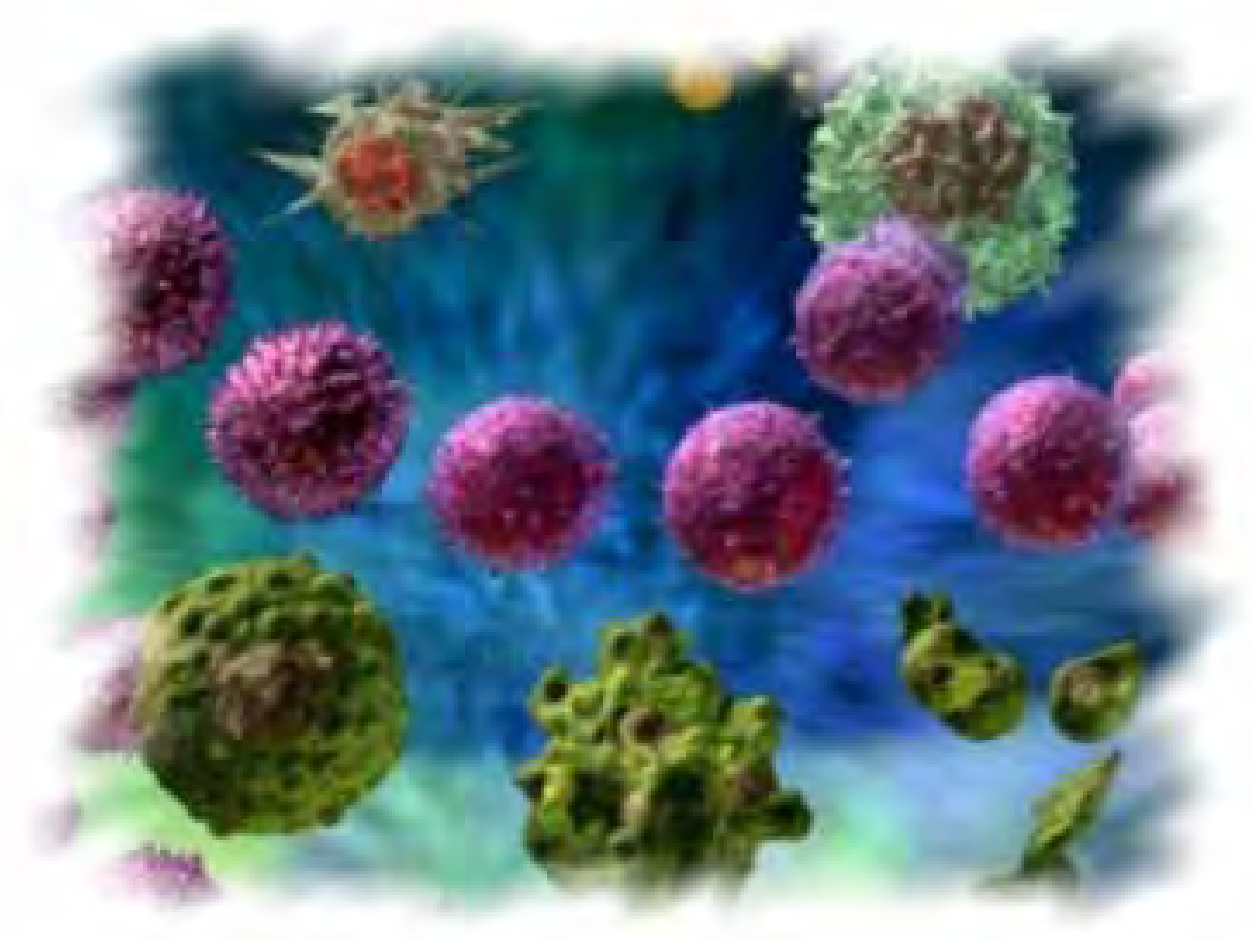

9. Summary 


\section{Abstract}

Introduction: The epithelial ovarian cancer represents a challenge to Gynecologic Oncology due to its insidious nature and high fatality. Evidences show that the immune system interacts with the tumor development and may be responsible for growth control and tumor regression. The adaptive immune response in the tumor environment, includes antibodies produced by $B$ cells and cellular immunity consisting of CD4 + and CD8 + T cells. This study aims to evaluate the adaptive immune response in peripheral blood of women with ovarian cancer.

Methods:. We analyzed peripheral blood samples obtained from healthy women ( $n=10$ - control group) with benign ovarian tumor $(n=9)$ and ovarian cancer $(n=17)$. The samples were evaluated by the technique of flow cytometry, where we used 5 parameters: cell size, internal complexity and three fluorescence: FITC, PE and TC. The panel of monoclonal antibodies included markers: CD4, CD8, HLA-DR, CD54, CD62L, CD18, CCR2, CXCR4, CCR5, CCR3, CXCR3, CD25, CD5, CD69, CD19, CD23, and isotype control. Differences between groups were evaluated by the Mann-Whitney or KruskalWallis tests. Differences with $p<0.05$ were considered significant.

Results: There was a significant decrease $(p<0.05)$ of the percentage of $T$ cells in the group of women with ovarian cancer when compared to the control group. The results showed that the percentage of CD4 $+\mathrm{T}$ cells showed significant differences between the groups $(p=0.0399)$. However the population of CD8+ T cells did not show significant differences ( $p=0.2939)$. The analysis of the percentage of B lymphocytes (CD19+) identified a significant difference between the three study groups $(p=0.0463)$. We observed a decrease in the percentage of $B$ cells of groups of women with benign tumor and ovarian cancer in the control group. Among the adhesion molecules tested (CD54, CD62L, CD18) showed significant decrease $(p<0.05)$ the number of $C D 4+C D 62 L+$ in the group of women with ovarian cancer when compared with the group of women with benign tumor. In the group of women 
with ovarian cancer there was a significant reduction $(p<0.05)$ the number of CD8 + T + CD62L when compared to the control group. It was possible to observe a statistically significant difference between groups CCR2 + CD8 + $(p=$ $0.0294), C D 8+C C R 5+(p=0.0216)$ and CD4 + CCR3 + $(p=0.0233)$.

Conclusion: It is possible to observe the participation of leukocytes in peripheral blood of patients with ovarian cancer, showing that the phenotypic events have as main feature the presence of systemic manifestations.

Keywords: epithelial ovarian cancer, adaptive immune response, immunophenotype, flow cytometry. 
1. Silva-Filho, A.L., et al., Cirurgia não Ginecológica em Pacientes com Câncer de Ovário. RBGO, 2004. 26(5): p. 411-416.

2. Jemal, A., et al., Cancer statistics, 2005. CA Cancer J Clin, 2005. 55(1): p. 1030 .

3. SOCIETY, A.C., Cancer Facts \& Figures 2009. American Cancer Society, 2009: p. 1-70.

4. Look, K., Epidemiology, etiology, and screening of ovarian cancer, in Ovarian cancer S.C. Rubin and G.P. Sutton, Editors. 2001, Lippincott Williams \& Wilkins: Philadelphia. p. 167-180.

5. Reis, F.M., et al., Biochemical markers of ovarian cancer: diagnostic and prognostic value. Italian Journal Of Gynaecology And Obstetrics, 2004. 16(3): p. 94-99.

6. Brewer, M.A., et al., Prevention of ovarian cancer: intraepithelial neoplasia. Clin Cancer Res, 2003. 9(1): p. 20-30.

7. Roett, M.A. and P. Evans, Ovarian cancer: an overview. Am Fam Physician, 2009. 80(6): p. 609-16.

8. $\quad$ Ries, L.A., et al., The annual report to the nation on the status of cancer, 19731997, with a special section on colorectal cancer. Cancer, 2000. 88(10): p. 2398-424.

9. Medzhitov, R. and C.A. Janeway, Jr., How does the immune system distinguish self from nonself? Semin Immunol, 2000. 12(3): p. 185-8; discussion 257-344.

10. Moser, M. and K.M. Murphy, Dendritic cell regulation of TH1-TH2 development. Nat Immunol, 2000. 1(3): p. 199-205.

11. Constant, S.L. and K. Bottomly, Induction of Th1 and Th2 CD4+ T cell responses: the alternative approaches. Annu Rev Immunol, 1997. 15: p. 297322.

12. Andres, P.G., et al., Mice with a selective deletion of the CC chemokine receptors 5 or 2 are protected from dextran sodium sulfate-mediated colitis: lack of CC chemokine receptor 5 expression results in a NK1.1+ lymphocyteassociated Th2-type immune response in the intestine. J Immunol, 2000. 164(12): p. 6303-12.

13. Svanborg, C., G. Godaly, and M. Hedlund, Cytokine responses during mucosal infections: role in disease pathogenesis and host defence. Curr Opin Microbiol, 1999. 2(1): p. 99-105.

14. Reid, R.R., et al., The role of complement receptors CD21/CD35 in positive selection of B-1 cells. Curr Top Microbiol Immunol, 2000. 252: p. 57-65.

15. Bos, N.A., J.J. Cebra, and F.G. Kroese, B-1 cells and the intestinal microflora. Curr Top Microbiol Immunol, 2000. 252: p. 211-20.

16. Berland, R. and H.H. Wortis, Origins and functions of B-1 cells with notes on the role of CD5. Annu Rev Immunol, 2002. 20: p. 253-300.

17. Bouvier, M., Accessory proteins and the assembly of human class I MHC molecules: a molecular and structural perspective. Mol Immunol, 2003. 39(12): p. 697-706.

18. Sezerman, U., S. Vajda, and C. DeLisi, Free energy mapping of class I MHC molecules and structural determination of bound peptides. Protein Sci, 1996. 5(7): p. 1272-81. 
19. Mieno, M., et al., CD4-CD8- T cell receptor alpha beta T cells: generation of an in vitro major histocompatibility complex class I specific cytotoxic T lymphocyte response and allogeneic tumor rejection. J Exp Med, 1991. 174(1): p. 193-201.

20. Voelk1, S., et al., Characterization of MHC class-I restricted TCRalphabeta+ CD4- CD8- double negative $T$ cells recognizing the gp100 antigen from a melanoma patient after gp100 vaccination. Cancer Immunol Immunother, 2009. 58(5): p. 709-18.

21. Fremont, D.H., et al., Structures of an MHC class II molecule with covalently bound single peptides. Science, 1996. 272(5264): p. 1001-4.

22. Brocke, P., et al., HLA-DM, HLA-DO and tapasin: functional similarities and differences. Curr Opin Immunol, 2002. 14(1): p. 22-9.

23. Villadangos, J.A., Presentation of antigens by MHC class II molecules: getting the most out of them. Mol Immunol, 2001. 38(5): p. 329-46.

24. Williams, A., C.A. Peh, and T. Elliott, The cell biology of MHC class I antigen presentation. Tissue Antigens, 2002. 59(1): p. 3-17.

25. Dranoff, G., Cytokines in cancer pathogenesis and cancer therapy. Nat Rev Cancer, 2004. 4(1): p. 11-22.

26. Dunn, G.P., L.J. Old, and R.D. Schreiber, The immunobiology of cancer immunosurveillance and immunoediting. Immunity, 2004. 21(2): p. 137-48.

27. Whiteside, T.L., Immune responses to malignancies. J Allergy Clin Immunol, 2003. 111(2 Suppl): p. S677-86.

28. Zhang, L., et al., Intratumoral $T$ cells, recurrence, and survival in epithelial ovarian cancer. N Engl J Med, 2003. 348(3): p. 203-13.

29. Pages, F., et al., Effector memory $T$ cells, early metastasis, and survival in colorectal cancer. N Engl J Med, 2005. 353(25): p. 2654-66.

30. Clark, W.H., Jr., et al., Model predicting survival in stage I melanoma based on tumor progression. J Natl Cancer Inst, 1989. 81(24): p. 1893-904.

31. Matzinger, P., The danger model: a renewed sense of self. Science, 2002. 296(5566): p. 301-5.

32. Gabrilovich, D., Mechanisms and functional significance of tumour-induced dendritic-cell defects. Nat Rev Immunol, 2004. 4(12): p. 941-52.

33. Zisman, A., A.J. Pantuck, and A. Belldegrun, Immune and genetic therapies for advanced renal cell carcinoma. Rev Urol, 2000. 2(1): p. 54-60.

34. Moretta, A., et al., What is a natural killer cell? Nat Immunol, 2002. 3(1): p. 68.

35. Dunn, G.P., L.J. Old, and R.D. Schreiber, The three Es of cancer immunoediting. Annu Rev Immunol, 2004. 22: p. 329-60.

36. Hollenbeak, C.S., et al., Increased incidence of melanoma in renal transplantation recipients. Cancer, 2005. 104(9): p. 1962-7.

37. Rosenberg, S.A., J.C. Yang, and N.P. Restifo, Cancer immunotherapy: moving beyond current vaccines. Nat Med, 2004. 10(9): p. 909-15.

38. Shah, C.A., et al., Intratumoral $T$ cells, tumor-associated macrophages, and regulatory T cells: association with p53 mutations, circulating tumor DNA and survival in women with ovarian cancer. Gynecol Oncol, 2008. 109(2): p. 215-9.

39. Tomsova, M., et al., Prognostic significance of CD3+ tumor-infiltrating lymphocytes in ovarian carcinoma. Gynecol Oncol, 2008. 108(2): p. 415-20. 
40. Leffers, N., et al., Prognostic significance of tumor-infiltrating T-lymphocytes in primary and metastatic lesions of advanced stage ovarian cancer. Cancer Immunol Immunother, 2009. 58(3): p. 449-59.

41. Wang, X., et al., Monocyte/macrophage and T-cell infiltrates in peritoneum of patients with ovarian cancer or benign pelvic disease. J Transl Med, 2006. 4: p. 30.

42. Ness, R.B. and C. Cottreau, Possible role of ovarian epithelial inflammation in ovarian cancer. J Natl Cancer Inst, 1999. 91(17): p. 1459-67.

43. Dietl, J., J.B. Engel, and J. Wischhusen, The role of regulatory $T$ cells in ovarian cancer. Int J Gynecol Cancer, 2007. 17(4): p. 764-70.

44. Hung, C.F., et al., Antigen-specific immunotherapy of cervical and ovarian cancer. Immunol Rev, 2008. 222: p. 43-69.

45. Andrade, S.P., et al., Sponge-induced angiogenesis in mice and the pharmacological reactivity of the neovasculature quantitated by a fluorimetric method. Microvasc Res, 1997. 54(3): p. 253-61.

46. Sakaguchi, S., et al., Immunologic tolerance maintained by CD25+ CD4+ regulatory $T$ cells: their common role in controlling autoimmunity, tumor immunity, and transplantation tolerance. Immunol Rev, 2001. 182: p. 18-32.

47. Adams, S.F., et al., Intraepithelial T cells and tumor proliferation: impact on the benefit from surgical cytoreduction in advanced serous ovarian cancer. Cancer, 2009. 115(13): p. 2891-902.

48. Hamerman, J.A., K. Ogasawara, and L.L. Lanier, NK cells in innate immunity. Curr Opin Immunol, 2005. 17(1): p. 29-35.

49. Nelson, B.H., The impact of T-cell immunity on ovarian cancer outcomes. Immunol Rev, 2008. 222: p. 101-16.

50. Morgan, E., et al., Cytometric bead array: a multiplexed assay platform with applications in various areas of biology. Clin Immunol, 2004. 110(3): p. 252-66.

51. Pierangeli, S.S., L.K. Silva, and E.N. Harris, A flow cytometric assay for the detection of antiphospholipid antibodies. Am Clin Lab, 1999. 18(6): p. 18-9.

52. Lund-Johansen, F., et al., Flow cytometric analysis of immunoprecipitates: highthroughput analysis of protein phosphorylation and protein-protein interactions. Cytometry, 2000. 39(4): p. 250-9.

53. Sato, E., et al., Intraepithelial CD8+ tumor-infiltrating lymphocytes and a high CD8+/regulatory $T$ cell ratio are associated with favorable prognosis in ovarian cancer. Proc Natl Acad Sci U S A, 2005. 102(51): p. 18538-43.

54. Naito, Y., et al., CD8+ T cells infiltrated within cancer cell nests as a prognostic factor in human colorectal cancer. Cancer Res, 1998. 58(16): p. 3491-4.

55. Nakano, O., et al., Proliferative activity of intratumoral CD8(+) T-lymphocytes as a prognostic factor in human renal cell carcinoma: clinicopathologic demonstration of antitumor immunity. Cancer Res, 2001. 61(13): p. 5132-6.

56. Bellati, F., et al., Immunology of gynecologic neoplasms: analysis of the prognostic significance of the immune status. Curr Cancer Drug Targets, 2009. 9(4): p. 541-65.

57. Bukowski, R.M., et al., Signal transduction abnormalities in T lymphocytes from patients with advanced renal carcinoma: clinical relevance and effects of cytokine therapy. Clin Cancer Res, 1998. 4(10): p. 2337-47.

58. Zou, W., Regulatory $T$ cells, tumour immunity and immunotherapy. Nat Rev Immunol, 2006. 6(4): p. 295-307. 
59. Balkwill, F., Cancer and the chemokine network. Nat Rev Cancer, 2004. 4(7): p. 540-50.

60. Wang, J.M., et al., Chemokines and their role in tumor growth and metastasis. J Immunol Methods, 1998. 220(1-2): p. 1-17.

61. Wong, M.M. and E.N. Fish, Chemokines: attractive mediators of the immune response. Semin Immunol, 2003. 15(1): p. 5-14.

62. Veneri, D., et al., Peripheral blood CD5-positive B lymphocytes (B-1 a cells) after allogeneic stem cell transplantation for acute myeloid leukaemia in humans. Blood Transfus, 2008. 6(4): p. 220-4.

63. Catelan, T.T.T., et al., Linfócitos B: da imunobiologia aos imunobiológicos. Sinopse de Reumatologia, 2008: p. 35-57. 